NBER WORKING PAPER SERIES

\title{
PENSION FUNDING, PENSION ASSET ALLOCATION, AND CORPORATE FINANCE: \\ EVIDENCE FROM INDIVIDUAL COMPANY DATA
}

Benjamin M. Friedman

Working Paper No. 957

\author{
NATIONAL BUREAU OF ECONOMIC RESEARCH \\ 1050 Massachusetts Avenue \\ Cambridge MA 02138
}

\author{
August 1982
}

The research reported here is part of the NBER's research programs in Financial Markets and Monetary Economics and in Pensions. Any opinions expressed are those of the author and not those of the National Bureau of Economic Research. 
NBER Working Paper \#957

August 1982

PENSION FUNDING, PENSION ASSET ALLOCATION, AND CORPORATE FINANCE:

EVIDENCE FROM INDIVIDUAL COMPANY DATA

\section{$\underline{\text { Abstract }}$}

This paper examines the relationship between U.S. corporations' management of their pension plans and their management of the more familiar aspects of corporate financial structure. The chief conclusion, on the basis of data for 7,828 pension plans sponsored by 1,836 companies and their subsidiaries, is that corporations do not manage the pension plans which they sponsor as if these plans had nothing to do with the corporation. Different responses appear to characterize firms' behavior in different contexts, but the evidence persistently indicates clear relationships between decisions about pension assets and liabilities and decisions about the other assets and liabilities of the firm. At the same time, the pattern of these relationships is, more often than not, inconsistent with familiar hypotheses that have emerged thus far in the theoretical literature analyzing pension aspects of corporate finance. Hence the conclusion from the data is also that the connections between pension decisions and corporate financial decisions in the more conventional sense are, at least as yet, not well understood.

Benjamin M. Friedman Harvard University Littauer Center 127 Cambridge, MA 02138 (617) $495-4246$ 


\section{PENSION FUNDING, PENSION ASSET ALLOCATION, AND CORPORATE FINANCE: EVIDENCE FROM INDIVIDUAL COMPANY DATA}

Benjamin M. Friedman*

Harvard University

Private pension funds now constitute one of the largest pools of investment assets in the United States. Their total assets exceed $\$ 300$ billion, and for the foreseeable future they are almost certain to grow still further in relation to the overall size of the U.S. financial markets. These funds already comprise by far the largest major category of institutional investor in the U.S. corporate equity market, and the second largest (after the life insurance industry) in the corporate bond market. As private pension funds continue to account for a steadily growing share of these key markets, their behavior becomes increasingly important to the understanding of how the U.S. financial markets determine the yields on, and prices of, financial assets.

At the same time, both the assets held by private pension plans and these plans' liabilities for future benefit payments are now large - and growing - in relation to the non-pension assets and liabilities of the U.S. private business sector. Many major corporations' pension assets and pension liabilities represent substantial fractions of the net worth of the company, and in some cases even bulk large in comparison to the company's total assets. Because corporate equity shares therefore represent ownership claims on two pools of assets, and obligations via two sets of liabilities, shareholders clearly have a direct interest in the company's pension plan in addition to the quantities that appear on 
its balance sheet. The larger are the assets and liabilities of the company's pension plan, the greater is their role, along with the nonpension assets and liabilities, in determining the sponsoring company's overall risk-return prospects. Hence private pension plans increasingly matter not just for employees but for corporations' shareholders and, in the event of default, corporations' creditors.

The growing importance of pension plans' assets and liabilities for nearly all constituencies within a typical corporation raises the possibility that the corporation's overall financial position and prospects may influence its strategy for funding its pension liabilities, as well as its subsequent allocation of these funds among alternative investment assets, in any of a number of ways. Companies may use unfunded pension liabilities as a substitute for credit market debt, or alternatively to extend overall indebtedness in conjunction with credit market debt. Similarly, companies may invest pension assets so as to mitigate, or alternatively to compound, the leverage and other risk-determining characteristics of their business. Then, too, there may be no connection at all - perhaps because managements feel a responsibility to subordinate the corporation's interest in its pension plan to the interests of the plan's beneficiaries.

Moreover, as private pension assets and liabilities continue to grow in relation to the balance sheet of the typical corporation, the possibility arises that the connection between corporate finance and pensions may be as relevant for understanding the former as the latter. If companies face limitations on the management of their pension assets and liabilities (as they do under the 1974 Employee Retirement Income Security ACt), or if the treatment for tax purposes of any specific asset 
or liability depends on whether it falls within the pension (as it does under the current U.S. Tax Code), then the desired positioning of the company's consolidated pension plan and balance sheet may not be attainable solely through actions executed in the pension plan. In such circumstances companies may take at least some features of (or constraints on) the pension plan as given in making decisions about the structure of their other assets and liabilities. More generally, a company may act so as to determine the structure of its pension plan and that of its balance sheet jointly.

The object of this paper is to test empirically for interrelationships along just these lines between U.S. corporations' management of their pension plans and their management of the more familiar aspects of corporate financial structure. One motivation underlying this effort is to subject to empirical scrutiny some of the theoretical hypotheses that have already emerged in the nascent literature of private pensions and corporate finance. In addition, the goal is to examine the data more broadly, to allow other regularities to appear which may be suggestive in the further development of theory describing these aspects of corporations' financial behavior.

Because of the overwhelming heterogeneity of both pension arrangements and financial structure within the U.S. corporate business sector, as well as the profusion of powerful economic, regulatory, and other institutional influences that have shaped the pension and general corporate financial environments in recent years, any attempt to conduct such an investigation using aggregated time-series data would be of limited value. Instead, the analysis undertaken here relies on individual company data assembled from the pension plan information that each plan sponsor 
provides to the Internal Revenue Service and the U.S. Department of Labor on Form 5500, used in conjunction with additional conventional individual company financial statistics contained in the Standard and Poor's Compustat file. The pension data are for plan year 1977, the only year for which a nearly complete Form 5500 file exists as of the time of writing.

Section I describes the data and indicates the procedures used for such steps as within-firm aggregation of multiple pension plans, merging of the Form 5500 and Compustat files, and treatment of corporate parent-subsidiary relationships. Section II, which focuses on pension funding strategy, presents the results of a series of tests for relationships between corporations' funding of their pension liabilities (the total of which is taken as given here) and other characteristics of the respective firms' business and balance sheet (also taken as given). Section III, also on pension funding strategy, digresses to examine the results of tests of the familiar hypothesis that corporations' decisions in this regard are oriented not to achieving fundamental financial objectives but to smoothing their reported earnings statements over time. Section IV, which focuses on pension asset allocations, presents the results of a series of tests for relationships between corporations' investment of their pension assets (the total of which is taken as given here) and other characteristics of the firm's business and balance sheet (also taken as given). Section $\mathrm{V}$ generalizes the line of investigation pursued in section II by presenting results of tests for a joint relationship between pension funding strategy and the corporation's balance sheet, thereby allowing for the possibility that balance sheet 
decisions may not be predetermined with respect to pension funding decisions. Section VI briefly summarizes the paper's principal conclusions, highlights some important caveats, and indicates directions for potential future research. 
I. The Data

The Employee Retirement Income Security Act of 1974 requires each pension benefit plan sponsored by a U.S. corporation to file a report annually, with the Internal Revenue Service and the Department of Labor, on Form 5500 (or Form 5500-C if the plan covers 100 or fewer participants). The form includes information about the plan's benefit structure, the number and current status of the participants in the plan, the plan's income and expenses for the year, and the plan's beginning-of-year and end-of-year assets broken down into a substantial detail of investment categories. Each defined benefit plan must also file Form 5500 schedule B, which provides actuarial information about the plan's accrued liabilities, including its vested and non-vested liabilities separately, together with other related items. The Appendix shows the format of Form 5500 and Schedule B.

The 1977 Employee Benefit plan Sample File contains all 29,120 Form 5500 returns submitted for plan year 1977 and processed by the Internal Revenue Service between July 1, 1978, and June 30,1979. 1 Those returns constituted $77.5 \%$ of the Form 5500 returns ultimately submitted for plan year 1977. The 22.58 of the returns that are missing from the file are heavily concentrated among smaller plans (as measured by asset size), however. $^{2}$ of the 29,120 returns included in the file, 4,694 either pertained to plans sponsored by non-profit organizations or reported zero assets. The remaining 24,426 returns form the basic sample used in this paper. Table 1 shows the distribution of assets across this sample of 24,426 plans. The combined assets for all 24,426 totaled $\$ 222$ billion. ${ }^{3}$ The great majority of this $\$ 222$ billion was concentrated in a small fraction 


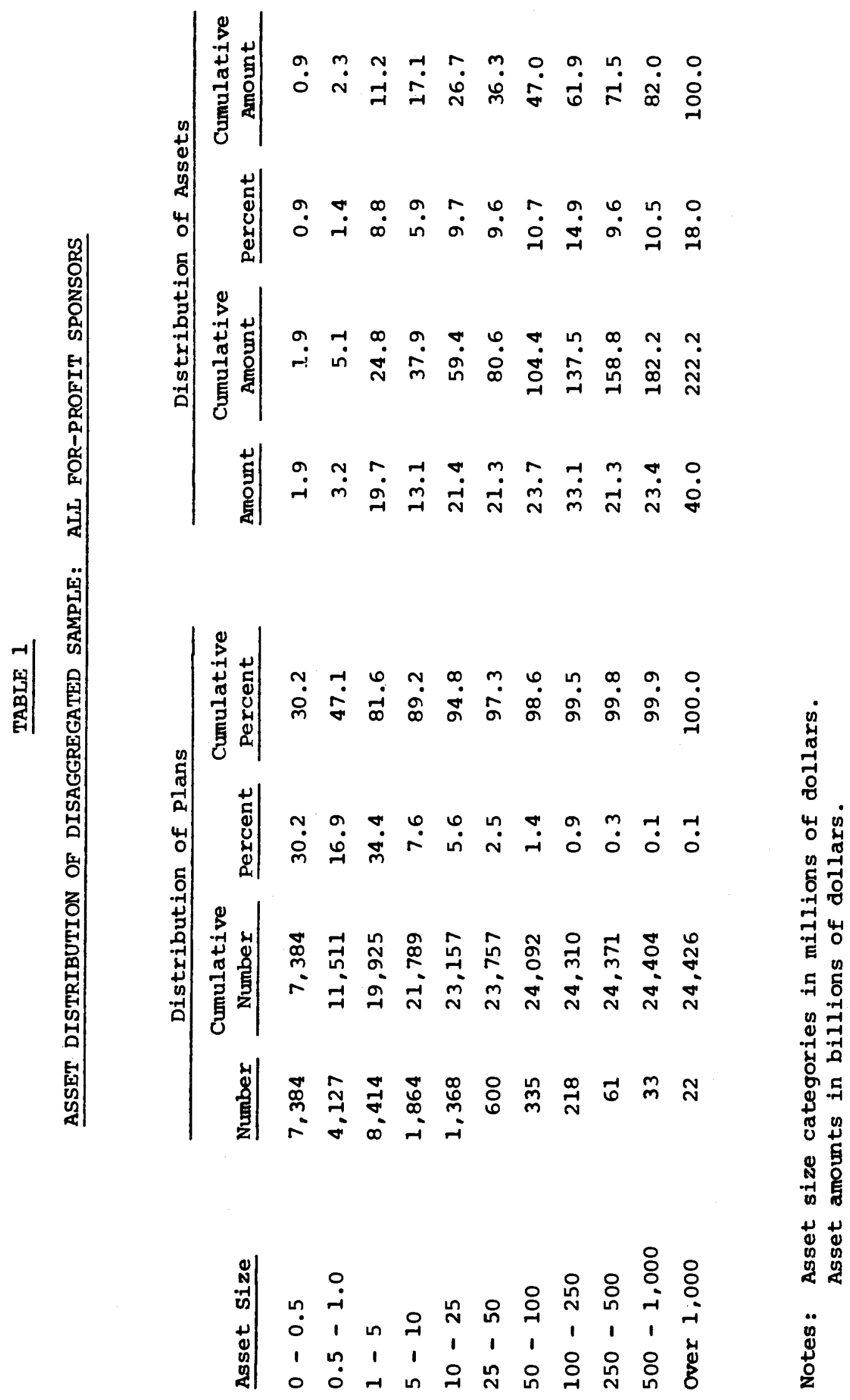


of the plans. Nearly one-half of the plans had less than $\$ 1$ million in assets, and more than four-fifths had less than $\$ 5$ million. By contrast, the 22 plans with more than $\$ 1$ billion in assets together accounted for almost one-fifth of the total, and the 55 plans with more than $\$ 500$ million together accounted for almost one-third. ${ }^{4}$

Because many companies sponsor more than one pension plan - one plan for salaried staff and another for wage earners, for example - the 24,426 plans in the sample represented only 15,098 sponsoring corporations. 5 For purposes of testing hypotheses about relationships between pension asset and liability decisions and corporate financial behavior in the conventional sense, what presumably matters is not the assets or liabilities of any one of a corporation's pension plans but the combined assets and liabilities of all plans that it sponsors. Table 2 shows the distribution of the $\$ 222$ billion in total assets across the 15,098 sponsoring firms in the sample. As is to be expected, aggregating all plans sponsored by a single firm shifts the distribution toward larger assets for each observation, although the effect is quantitatively small.

The most common form of pension plan in the United States is the defined benefit plan, but other forms (primarily the defined contribution plan) exist as well. The distinction is relevant because the concept of pension "liabilities" has meaning only for defined benefit plans. For the same reason, shareholders in a corporation have no direct financial interest in how the assets of a defined contribution plan perform. Of the 24,426 plans in Table 1, 16,200 sponsored by 10,470 different companies, and with $\$ 165$ billion in assets, were defined benefit plans. Nevertheless, 856 of these plans failed to file Schedule $B$ in time for the Internal Revenue service to process it, along with the corresponding Form 5500 


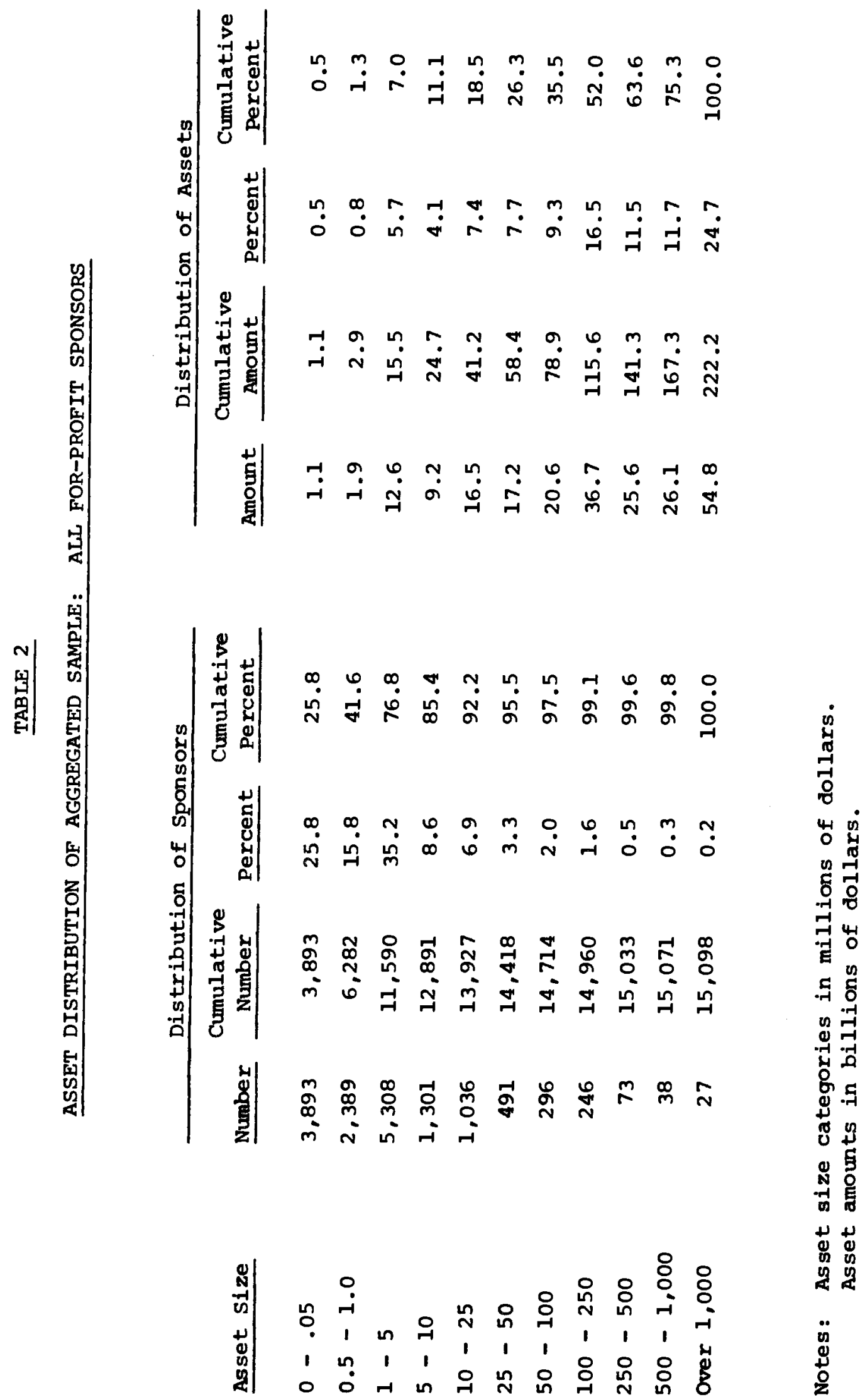


return, before June 30,1979 . The remaining 15,344 plans, sponsored by 9,899 companies, reported $\$ 152$ billion in cambined assets. Table 3 shows the distribution of these assets across the 9,899 firms.

The information contained in Form 5500 is insufficient, of course, to facilitate tests of hypotheses about relationships between pension asset and liability decisions and corporate finance decisions in the conventional sense. Some source of information about each sponsoring company's balance sheet, as well as its income statement and other aspects of its financial situation, is also necessary. Because many of the 15,098 companies sponsoring pension plans included in the 1977 Form 5500 sample are either small or closely held, however, obtaining such information on a comprehensive basis would be impractical if not impossible. By contrast, most of the larger companies are included in the Standard \& Poor's Compustat file. A systematic search, based on a computer procedure supplemented with "by hand" inspection, revealed 1,690 corporations included in the Compustat file that were sponsors of 5,788 pension plans included in the 1977 Form 5500 sample. 6

Even so, simply matching Compustat firms with pension plan sponsors would still be inadequate. The Compustat file reports balance sheets and earnings statements for each included corporation on a consolidated basis - that is, including all of the corporation's wholly owned subsidiaries. From the perspective of analyzing corporate financial behavior at the level of the relationships posited in this investigation, consolidation is presumably the correct procedure. Matching Compustat firms with pension plan sponsors would be inadequate, therefore, without also consolidating plans sponsored by each Compustat firm with plans sponsored by its subsidiaries (if any). A laborious "by hand" search indeed revealed that 593 compustat firms were sponsors - not directly, but through subsidiaries - of 2,040 


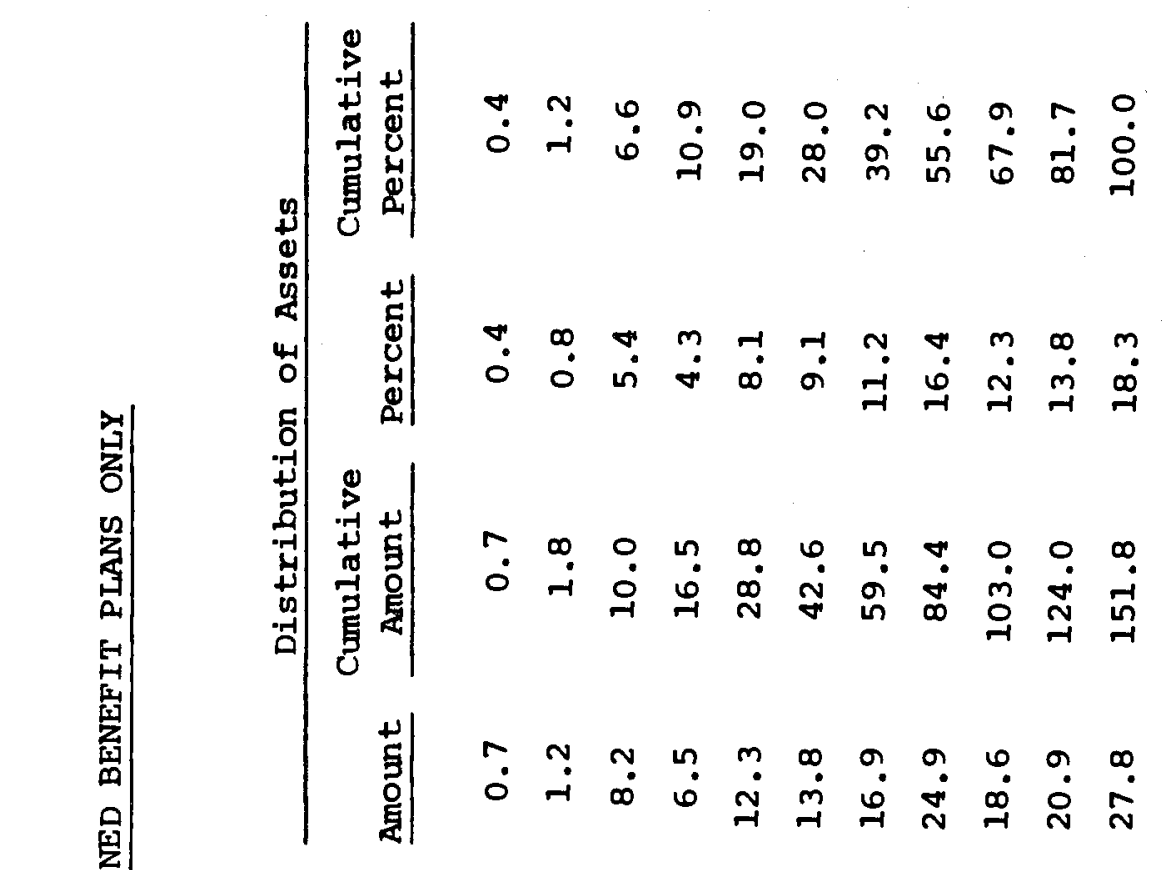

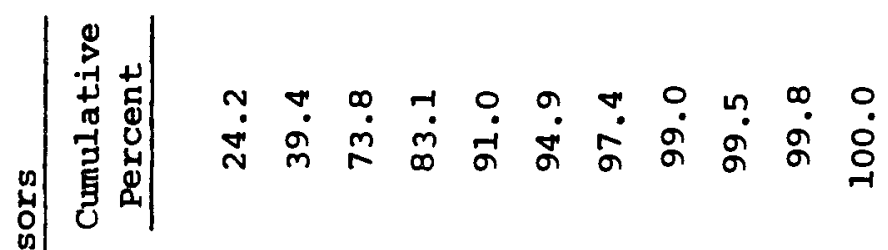

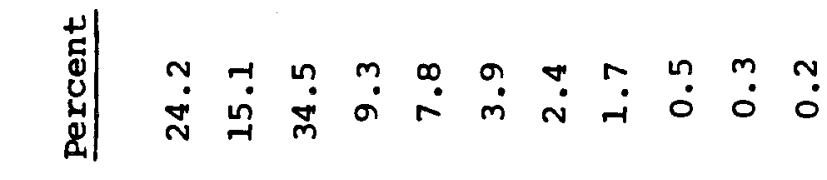

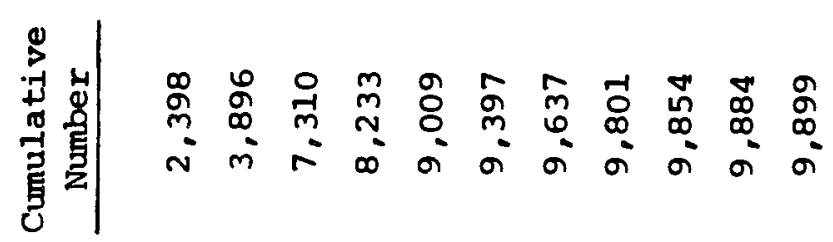

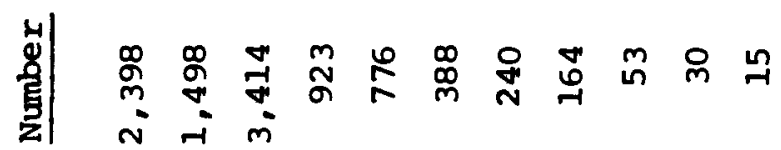

$\frac{\dot{0}}{4}$

出点

है न당

8
-7
-7

당

.

ด न-1

. 댕

옥ㄷ

북

ตู

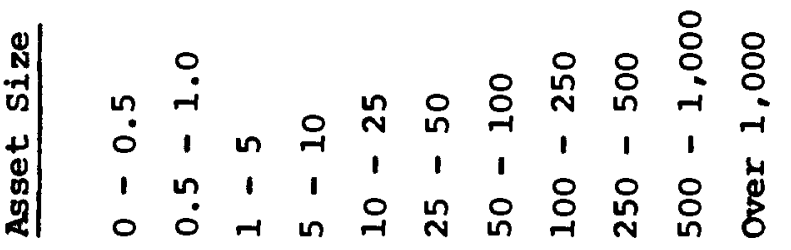

焉焉

$\ddot{g}$ 
pension plans included in the 1977 Form 5500 sample. ${ }^{7}$ of the 593 compustat firms sponsoring pension plans through subsidiaries, 447 also sponsored one or more plans directly.

The fully aggregated and consolidated sample available for use in testing for relationships between pension decisions and corporate financial decisions therefore consists of 7,828 pension plans (including defined benefit as well as other type plans, and, among defined benefit plans, those that did and did not file schedule B), with $\$ 153$ billion in combined assets, sponsored by 1,836 consolidated companies. ${ }^{8}$ Table 4 shows the distribution of the $\$ 153$ billion of assets across the 1,836 firms. Of the 7,828 plans sponsored by consolidated Compustat companies, 5,836 were defined benefit plans, of which 5,670 filed schedule $B$ in time for Internal Revenue Service processing. Table 5 shows the distribution of these 5,670 plans' $\$ 110$ billion of assets across the plans' 1,552 sponsoring firms. A comparison of Tables 2 and 4 , and of Tables 3 and 5 , shows that the result of not only consolidating subsidiaries into parent companies but also excluding all plans not sponsored by a compustat firm (even through a subsidiary) is to shift the distribution further toward larger dollar amounts per company. 9 

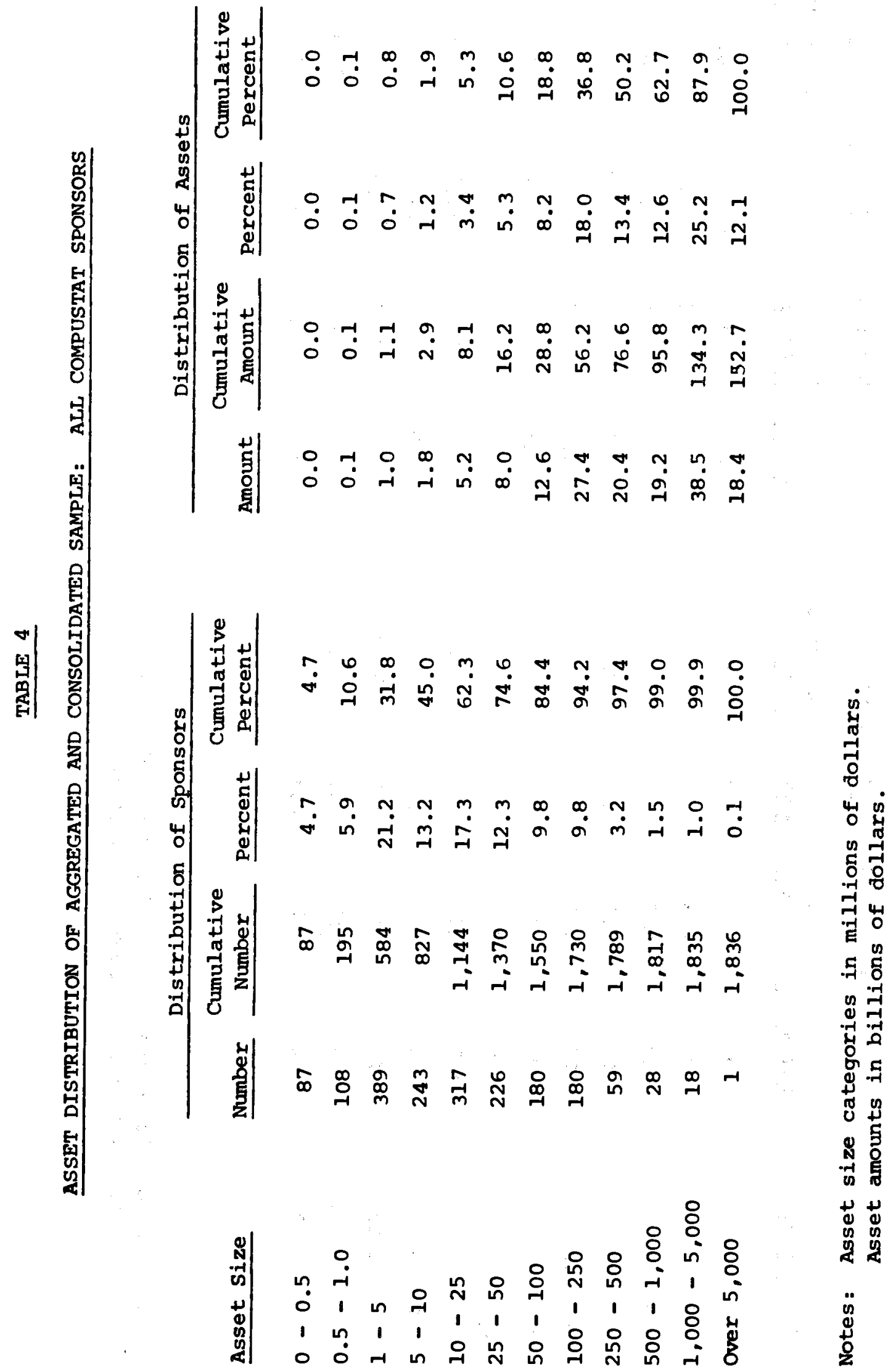


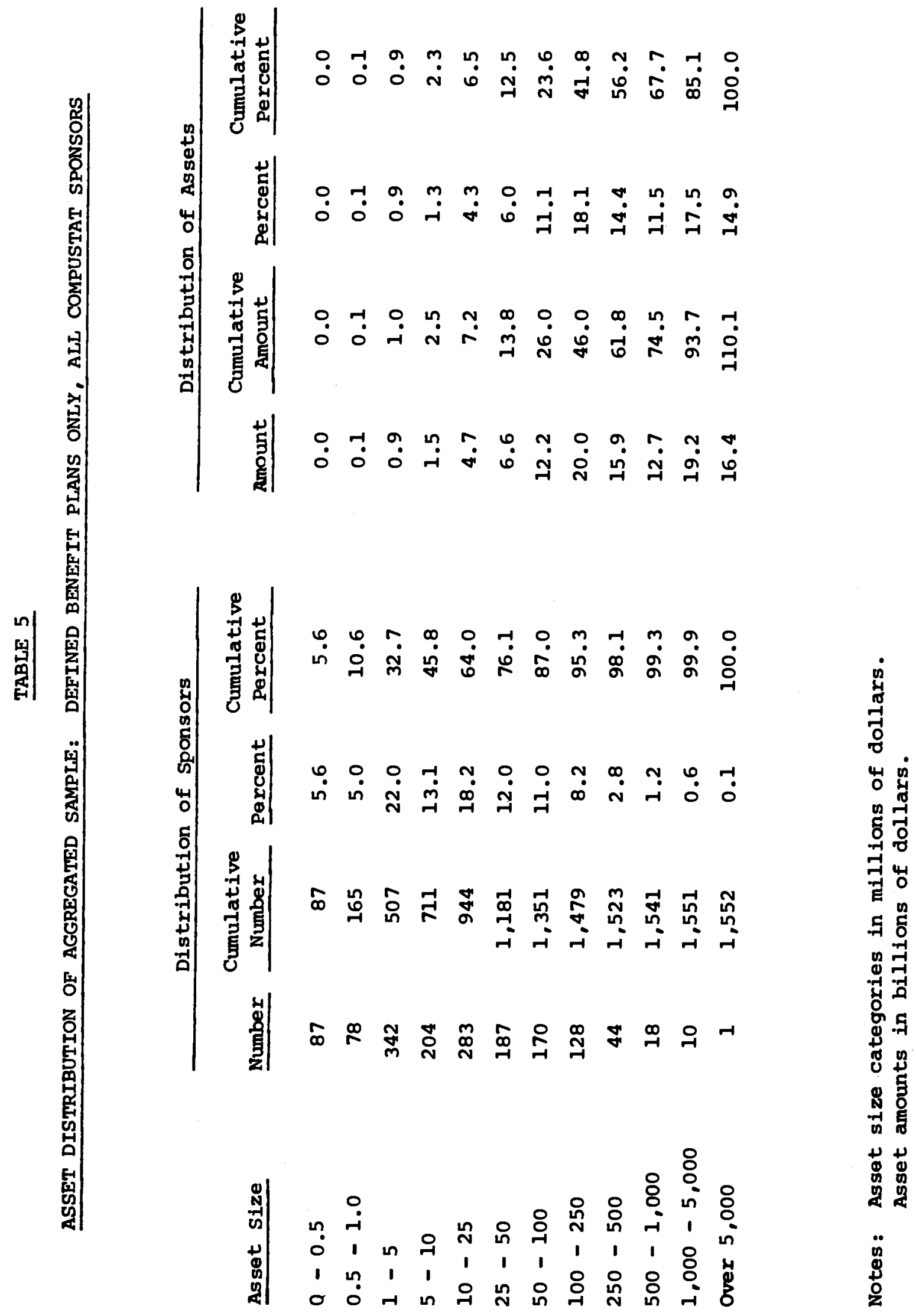




\section{Pension Funding Strategy}

In the most abstract conception of the incorporated firm, the assets and liabilities of a corporation's defined benefit pension plan(s) are just like the assets and liabilities that appear on its balance sheet. Shareholders own both sets of assets, and they are responsible (to the extent of their equity) for both sets of liabilities. Whether the firm's management acts so as to maximize the share price, to maximize expected profits, or to achieve yet some other objective, there is no need to distinguish between one pool of assets and the other, or between one group of liabilities and the other.

Such an abstraction may fail to describe the world of U.S. corporations and their sponsored pension plans for several well-known reasons. 10 At the most practical level, the firm's flexibility on the pension liability side is usually severely limited. Conventions of labor market practice, reinforced by legal requirements and often by collective bargaining agreements, restrict the range within which a firm and its workers can divide total labor costs between current and deferred compensation. To the extent that the firm's basic pension liabilities are predetermined from the perspective of financial decision making, therefore, its choice of pension "liabilities" in this context refers only to that part of the basic actuarial liability in excess of the amount of assets conmitted to the pension fund. Hence decisions about pension "liabilities" in this sense are really decisions about pension assets. Moreover, the firm's flexibility is limited here too, in that its pension funding position must meet standards specified by the Employee Retirement Income security Act. ${ }^{11}$

Wholly apart from such constraints, a variety of considerations may lead the firm to see pension assets and liabilities as less than perfect 
substitutes for its other assets and liabilities. First, the implicit cost of "borrowing" by less than fully funding pension liabilities need not be identical, either before or after taxes, to the explicit cost of borrowing in the credit market. In the extreme, the former "source of funds" may be available at times when the latter is not. Even under ordinary circumstances, the scheduling of the "debt service" associated with the two kinds of liabilities may differ in important ways. A second distinction is that pension liabilities, unlike the firm's other liabilities in most circumstances, are insured in a way that limits the firm's exposure. The Pension Benefit Guarantee Corporation insures corporations' pension liabilities in full but, in the event of default, has a claim on only one-third of the firm's assets. The tax treatment of pension plans provides a third reason why the simple abstraction, in which one asset or liability is just like any other, may not apply to actual corporations. Payments of funds into the pension plan are deductible from the firm's income for tax purposes, and earnings on assets held in the pension plan are excluded from taxable income. Finally - although these four factors do not exhaust the possible reasons for distinguishing pension versus other assets and liabilities - shareholders and potential shareholders may be more fully aware of that part of a firm's liabilities which actually appears on its balance sheet. 12

For all of these familiar reasons, therefore, a corporation may not behave as if it is indifferent between pension and other assets, or between pension and other liabilities. Hence instead of the usual net worth constraint 
where TA and TI are the firm's total assets and total liabilities, respectively, and $\mathrm{NW}$ is net worth (assumed to be predetermined as of any specific time), the more relevant expression is

$$
\mathrm{PA}+\mathrm{BA}-\mathrm{PI}-\mathrm{BI}=\mathrm{NW}
$$

where PA and PI distinguish the assets and liabilities of the firm's defined benefit pension plan(s), while $B A$ and $B I$ represent the assets and liabilities that appear on the firm's balance sheet. ${ }^{13}$

If the firm were free to choose simultaneously each of these four quantities, subject only to the net worth constraint, then its consolidated "portfolio" behavior would take the familiar form

$$
\frac{1}{N W}\left|\begin{array}{c}
P A \\
B A \\
-P I \\
-B L
\end{array}\right|=\underline{\alpha}+B X
$$

where $\underline{x}$ is a vector of external factors determining the firm's responses, $\underline{\alpha}$ is a vector of coefficients suming to unity, and $B$ is a matrix of coefficients with zero column sums. The most familiar empirical application of this conception is in a time-series context, in which $x$ would include primarily (often exclusively) the expected yields on the respective assets and liabilities. By contrast, in a cross-section context the elements of $\underline{X}$ are firm-specific factors that are taken to be predetermined with respect to the firm's portfolio choice in the one time period under observation, and that (at least potentially) influence that choice. To the extent that some of the firm's portfolio choices are predetermined with respect to others, however, some of the elements within the left-hand side of (3) 
belong more properly on the right. If the firm decides on its pension assets and liabilities only secondarily, after deciding on its other liabilities, then PA and PI may depend on $B A$ and $B L$ as well as the other factors included within $\underline{x}$.

One question that immediately arises in this context is whether firms have fixed targets for their total liabilities (PI + BL) so that they take on fewer pension liabilities as they have more liabilities on their balance sheets or, alternatively, whether they systematically use PL and BL together to achieve greater or lesser total leverage. Put in another way, the question is whether the firm treats pension liabilities and other liabilities as substitutes or complements, although the sense of substitutability versus complementarity involved here differs somewhat from the usual one in which vector $x$ includes specific time-varying yields associated with $\mathrm{PL}$ and $\mathrm{BL}$.

The evidence from the 1977 Form 5500 sample is consistent with complementarity of $\mathrm{PL}$ and $\mathrm{BL}$ in this sense. Estimating the cross-section regression

$$
\frac{\mathrm{PL}}{\mathrm{NW}}=\alpha+\gamma \frac{\mathrm{BL}}{\mathrm{NW}}
$$

for the sample of all consolidated Compustat firms with defined benefit plans filing schedule B yields $\gamma=.17$, with t-statistic $7.8\left(\bar{R}^{2}=.04\right) .14$ For the subsample in which each firm's pension plan is sufficiently important in its overall structure that pension liabilities amount to at least 38 of the firm's total assets, the result is $\gamma=.26$, with t-statistic $6.4\left(\bar{R}^{2}=.07\right)$. For the further subsample in which PI/TA $\geq .10$, the result is $\gamma=.50$, with t-statistic $7.9\left(\bar{R}^{2}=.17\right)$. 
Further analysis that controls for other influences in the spirit of (3), while maintaining the assumption that $\mathrm{BL}$ is predetermined with respect to PL, supports this conclusion. Table 6 reports estimation results for a series of regressions of the form

$$
\frac{\mathrm{PL}}{\mathrm{NW}}=\alpha+\gamma \frac{\mathrm{BL}}{\mathrm{NW}}+\beta \mathrm{X}
$$

where $\mathrm{x}$ is, in turn, each of a series of variables describing the firm and its operating environment. once again, the positive relationship between pension and other liabilities (both scaled by net worth) holds up regardless of the choice of additional controlling variable.

The specific results for the partial effects of the several controlling variables are also interesting in some cases. Neither the growth rate nor the trend-adjusted variability of the firm's earnings had a significant effect on its pension liabilities. The 1977 rate of return on assets affected pension liabilities positively, but the mean rate of return over the past ten years did not. The negative effect of the volatility of rate of return was marginally significant in the full sample, but not in the subsample with large pension liabilities relative to the firm's total assets. The firm's tax status had no significant effect. As would be expected, the firm's labor intensiveness affected pension liabilities positively, and the fraction of the firm's pension plan participants who were still employed affected pension liabilities negatively; but both effects were significant in the full sample only. The failure of so many basic aspects of the firm's risk and return situation to affect its pension liabilities supports the suggestion, made above, that the firm does not actually choose PL in the usual portfolio 
Full Sample

\section{Control Variable}

$\rho(E B I T)$

$\sigma(E B I T)$

$\mathbf{E} / \mathbf{B A}$

$\mu(E / B A)$

$\sigma(E / B A)$

$\mu(\mathrm{T} / \mathrm{E})$

$\mu(\mathrm{I} / \mathrm{s})$

AGE

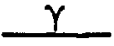

.17

(7.5)

.17

(7.5)

.20

(6.7)

.16

$(5.6)$

.15

(6.1)

.15

(6.5)

.20

(5.6)

.15

(6.1)

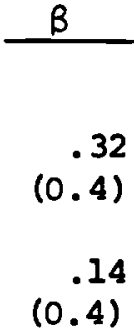

.60

(3.1)

.17

$(0.6)$

$-.81$

$(-1.9)$

.00

$(0.4)$

.23

(2.0)

$-.44$

$(-5.6)$
PL/TA $\geq .10$ Subsample

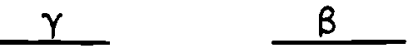

.51

$-.46$

$(7.6)$

$(-0.2)$

.51

1.20

(7.9)

(1.1)

.55

1.15

(6.8)

(2.0)

.46

.20

$(6.0)$

(0.2)

.46

$-.46$

$(6.8)$

$(-0.3)$

.46

(6.9)

$(1.0)$

.66

.21

(5. 7)

$(0.6)$

.44

$-.26$

(6.6)

$(-1.2)$

Note: Results shown are estimated coefficients (and t-statistics) for the regression

$$
\frac{\mathrm{PL}}{\mathrm{NW}}=\alpha+\gamma \frac{\mathrm{BL}}{\mathrm{NW}}+B \mathrm{X}
$$

\section{Variable Symbols:}

$\rho(E B I T)=$ ten-year growth rate of earnings before interest and taxes

$\sigma(E B I T)=$ ten-year normalized standard deviation of EBIT around its growth trend

$\mathrm{E} / \mathrm{BA}=$ ratio of earnings to non-pension assets

$\mu(\mathrm{E} / \mathrm{BA})=$ ten-year mean of $\mathrm{E} / \mathrm{BA}$

$\sigma(E / B A)=$ ten-year standard deviation of $E / B A$ around $\mu(E / B A)$

$\mu(T / E) \quad=$ five-year mean of ratio of taxes paid to before-tax earnings

$\mu(\mathrm{L} / \mathrm{S}) \quad=$ five-year mean of ratio of labor and related expenses to net sales

AGE

= ratio of pension plan participants currently employed to all plan participants 
sense. Instead, the firm may take PL as given - by labor market considerations, for example - so that its actual choice in this context is simply how much of its pension liabilities to fund. If the firm were free to choose in this context, its portfolio problem would take the form

$$
\frac{1}{N W}\left|\begin{array}{c}
B A \\
-B L \\
-(P L-P A)
\end{array}\right|=\underline{\alpha}+B \underline{X} .
$$

Moreover, if the firm decides only secondarily on its unfunded pension liabilities (that is, on its pension assets in this context), then again the possibility arises that (PL - PA) depends on $B A$ and $B L$ as well as on any or all of the other factors included within $\mathrm{x}$.

The parallel question in this context is whether firms with large amounts of debt on their balance sheet choose to have greater or smaller amounts of unfunded liabilities. In this form the question bears a direct connection to at least one prominent line of theoretical analysis of how corporations' pension funding decisions depend on their financial condition. In particular, Sharpe (1976) has suggested that an important rationale for firms to fund their pension plans less than fully is the value of the insurance provided by the Pension Benefit Guarantee Corporation (PBGC). 15 In Sharpe's analysis the insurance written by the PBGC is equivalent to a put option, and the firm's incentive is to maximize the value of the put. A major implication of this line of reasoning is that firms for which the probability of bankruptcy is nontrivial have an incentive to underfund their pension plans. The more highly levered a firm is, therefore - that is, the larger is BL relative to $\mathrm{NW}$, all other considerations equal - the greater 
is the firm's incentive to underfund its pension plan. In terms of the current analysis, therefore, the Sharpe hypothesis suggest that BL and (PL - PA) are complements.

The evidence from the 1977 Form 5500 sample is consistent with complementarity not only of $\mathrm{BL}$ and $\mathrm{PL}$, as in (4), but also of $\mathrm{BL}$ and (PL - PA). Hence the data are consistent with Sharpe's analysis of the pension funding decision. Estimating the cross-section regression

$$
\frac{P L-P A}{N W}=\alpha+\gamma \frac{B L}{N W}
$$

for the full sample yields $\gamma=.14$, with t-statistic $10.1\left(\bar{R}^{2}=.07\right) .^{16}$ For the subsample of firms with $P L / T A \geq .03$, the corresponding results are $\gamma=.25$, with t-statistic $9.3\left(\bar{R}^{2}=.13\right)$. For the subsample with $\mathrm{PL} / \mathrm{TA} \geq .10$, the results are $\gamma=.44$, with t-statistic $10.8\left(\overline{\mathrm{R}}^{2}=.27\right)$. Table 7 shows estimation results, comparable to those in Table 6 , for a parallel series of regressions

$$
\frac{P L-P A}{N W}=\alpha+\gamma \frac{B L}{N W}+B X
$$

that differ only in the assumption that the firm's choice variable is unfunded pension liabilities rather than total pension liabilities. Here Sharpe's analysis implies that aspects of the firm's operating environment that affect its probability of bankruptcy - variability of earnings, for example - should also increase the firm's incentive to underfund its pension. once again, the strong positive relationship between (unfunded) pension liabilities and the firm's other liabilities holds up regardless of the controlling variable. The results for the 


\begin{tabular}{|c|c|c|c|c|}
\hline \multirow[b]{2}{*}{ Control Variable } & \multicolumn{2}{|c|}{ Full Sample } & \multicolumn{2}{|c|}{$\mathrm{PL} / \mathrm{TA} \geq .10$ Subs ample } \\
\hline & $\gamma$ & $B$ & $\gamma$ & $\beta$ \\
\hline$\rho(\mathrm{EBIT})$ & $\begin{array}{r}.14 \\
(9.6)\end{array}$ & $\begin{array}{r}.13 \\
(0.3)\end{array}$ & $\begin{array}{r}.45 \\
(10.2)\end{array}$ & $\begin{array}{r}-.82 \\
(-0.4)\end{array}$ \\
\hline$\sigma(E B I T)$ & $\begin{array}{r}.14 \\
(9.7)\end{array}$ & $\begin{array}{r}.17 \\
(0.8)\end{array}$ & $\begin{array}{r}.45 \\
(10.8)\end{array}$ & $\begin{array}{l}1.05 \\
(1.3)\end{array}$ \\
\hline $\mathrm{E} / \mathrm{BA}$ & $\begin{array}{r}.15 \\
(7.3)\end{array}$ & $\begin{array}{r}.35 \\
(2.7)\end{array}$ & $\begin{array}{r}.48 \\
(8.1)\end{array}$ & $\begin{array}{r}.88 \\
(2.1)\end{array}$ \\
\hline$\mu(E / B A)$ & $\begin{array}{r}.12 \\
(6.5)\end{array}$ & $\begin{array}{r}.12 \\
(0.7)\end{array}$ & $\begin{array}{r}.42 \\
(7.5)\end{array}$ & $\begin{array}{r}.25 \\
(0.4)\end{array}$ \\
\hline$\sigma_{:}(\mathrm{E} / \mathrm{BA})$ & $\begin{array}{r}.12 \\
(7.0)\end{array}$ & $\begin{array}{r}-.32 \\
(-1.1)\end{array}$ & $\begin{array}{r}.41 \\
(8.4)\end{array}$ & $\begin{array}{r}.11 \\
(0.1)\end{array}$ \\
\hline$\mu(T / E)$ & $(7.2)$ & $\begin{array}{r}.00 \\
(0.4)\end{array}$ & $\begin{array}{r}.39 \\
(8.2)\end{array}$ & $\begin{array}{r}.05 \\
(1.1)\end{array}$ \\
\hline$\mu(L / S)$ & $\begin{array}{r}.16 \\
(7.4)\end{array}$ & $\begin{array}{r}.16 \\
(2.1)\end{array}$ & $\begin{array}{r}.53 \\
(8.0)\end{array}$ & $\begin{array}{r}.30 \\
(1.1)\end{array}$ \\
\hline AGE & $(7.12)$ & $\begin{array}{r}-.31 \\
(-6.0)\end{array}$ & $\begin{array}{r}.39 \\
(8.1)\end{array}$ & $\begin{array}{r}-.37 \\
(-2.4)\end{array}$ \\
\hline
\end{tabular}

Notes: Results shown are estimated coefficients (and t-statistics) for the regression

$$
\frac{P L-P A}{N W}=\alpha+\gamma \frac{B L}{N W}+B X
$$

See Table 6 for definitions of variable symbols. 
effects of the individual controlling variables are again about as in Table 6. In particular, neither volatility of earnings nor volatility of rate of return exhibits the significant positive effect that would be consistent with Sharpe's hypothesis.

Finally, the form of both (7) and (8) assumes not only that the firm takes its pension liabilities as given in deciding on pension funding, but also that the firm takes decisions solely on the difference (PI - PA) irrespective of either individual amount. In other words, (7) and (8) are equivalent, respectively, to

$$
\frac{\mathrm{PA}}{\mathrm{NW}}=\alpha+\delta \frac{\mathrm{PL}}{\mathrm{NW}}+\gamma \frac{\mathrm{BL}}{\mathrm{NW}}
$$

and

$$
\frac{P A}{N W}=\alpha+\delta \frac{P L}{N W}+\gamma \frac{B L}{N W}+B X
$$

subject to the constraint $\delta=1$. The data consistently reject this constraint, however. Estimating (9) for the full sample yields $\delta=.60$ and $\gamma=-.06$ with respective t-statistics 42.8 and $-4.9\left(\bar{R}^{2}=.59\right) .^{17}$ For the subsample with $\mathrm{PL} / \mathrm{TA} \geq .03$, the corresponding results are $\delta=.63$ and $\gamma=-.09$, with respective t-statistics 32.8 and $-4.4\left(\bar{R}^{2}=.66\right)$. For the subsample with $\mathrm{PL} / \mathrm{TA} \geq .10$, the results are $\delta=.66$ and $\gamma=-.16$, with respective t-statistics 22.6 and $-4.7\left(\bar{R}^{2}=.64\right)$. The results of estimating (10) with any of the control variables shown in Tables 6 and 7 indicate similar values for $\delta$ and $\gamma$, and $\beta$ values that are again consistent with those found in estimating (5) and (8).

Hence the firm-to-firm variation in pension funding does not simply reflect individual firms' decisions strictly about their unfunded liabilities. 
At the margin, with other factors equal, a firm with an additional $\$ 1$ of pension liabilities typically funds only about $60 \%$ more in pension assets. This marginal funding rate - marginal from one firm to the next, that is, rather than for one firm over time - is also just equal to the average funding ratio $(.62)$ for all firms in the sample. In addition, the consistent finding of a negative $\gamma$ value in (9) and (10) indicates that firms with greater amounts of non-pension liabilities fund their pension liabilities less fully, to the extent of about a 10 c reduction in pension funding for each $\$ 1$ of additional non-pension liabilities. This result is again consistent with Sharpe's analysis of the pension funding decision in the context of the value of the put to the PBGC.

The main conclusions that emerge from this consideration of the firm's choice of pension liabilities and funding, on the assumption that the asset and liability totals on the firm's balance sheet are predetermined with respect to its pension decisions, are (1) that pension liabilities, either in total or in excess of funding, depend positively on the firm's other liabilities; (2) that firms do not make decisions simply with respect to their unfunded pension liabilities, but instead fund pension liabilities less than one-for-one at the margin; (3) that funding of the firm's pension liabilities depends negatively on its other liabilities; and (4) that, apart from labor-specific characteristics like the firm's labor intensiveness and the working-retired status of its labor force, basic aspects of the firm's risk and return position have no apparent effect on its choice of either total or unfunded pension liabilities. 
III. The Earnings Smoothing Hypothesis

The discussion of pension funding strategy in section II focuses on fundamental aspects of portfolio behavior: substitutability versus complementarity of pension and other liabilities, the degree to which pension assets offset pension liabilities, and the role of other measures of risk and return confronting the firm. From the perspective of any familiar theory of corporate financial behavior, these considerations and others like them are the principal determinants of the firm's pension decisions.

By contrast, discussions of pension funding strategy by corporate practitioners often emphasize different factors. In particular, in seeking to explain why so many firms underfund their pension plans despite apparent tax incentives to fund fully, corporate financial officers and other financial market participants frequently cite the "hidden" nature of pension liabilities. Because the pension plan is off the balance sheet, shareholders and others may be at least partly unaware of the associated liabilities. The most obvious implication of this assertion is that a firm may be able to raise its share price by substituting pension liabilities for liabilities that appear on the balance sheet, but recent research on the relationship between stock prices and pension liabilities has provided evidence that typically warrants rejecting this proposition. ${ }^{18}$

A further implication of the idea that pension assets and liabilities are "hidden" is that shareholders and other interested persons may judge the firm's performance by its reported earnings, rather than by more comprehensive flow measures. Because contributions to a firm's pension plan reduce its reported earnings in the same way as any other expense item, control over the timing of pension contributions enables firms to influence the time path of reported earnings. To the extent that the management seeks 
to report smoothly growing earnings over time, therefore, it may want to increase pension contributions when business is strong and reduce them when business is weak. Such actions need not change the total amount contributed to the pension plan over time. Indeed, in the broader context that consolidates the firm's pension assets and liabilities with its other assets and liabilities, such actions change nothing at all. They have a purpose only if some constituency, whose actions matter to the corporation, focuses on the time path of reported earnings.

This earnings smoothing hypothesis provides a potential explanation for the pension underfunding puzzle to the extent that firms with unfunded pension liabilities have more flexibility to adjust the timing of their pension contributions than do firms with fully funded pensions. Restrictions on pre-funding unaccrued pension liabilities prevent a firm with a fully funded pension from making extraordinary increases in contributions, and firms that simply decide to fund fully choose thereby to forego using the potential flexibility in the opposite direction.

Data from the 1977 Form 5500 sample provide evidence indicating that firms typically do manage earnings in this way. For the entire sample of firms with defined benefit plans, $70.0 \%$ had before-tax reported earnings streams that were smoother, as measured by the normalized ten-year standard deviation around trend, than the corresponding consolidated earnings including pension contributions. On an after-tax basis, with the included pension contributions adjusted for additional taxes that the firm would otherwise have paid, 70.5 of firms had smoother reported earnings than consolidated earnings.

Nevertheless, the data provide almost no support for the claim that firms with underfunded pension liabilities are more likely to manage their 
reported earnings in this way. Table 8 shows the percentages of firms with smoother reported than consolidated earnings, comparable to the percentages reported above, for a break-down of the full sample according to the ratio of pension assets to pension liabilities. If anything, these distributions seem to indicate that firms with underfunded pension liabilites are less likely to engage in smoothing their reported earnings by managing their pension contributions. Only for the two extreme subsamples - with funding ratios below .10 or above .90 - does the relationship go in the hypothesized direction.

A more systematic examination of the data confirms this impression. Estimating the regression

$$
\frac{\sigma(E)}{\sigma(E+P C)}=\alpha+\beta \frac{P A}{P L}
$$

where $\sigma(E)$ and $\sigma(E+P C)$ are the normalized ten-year standard deviations of reported earnings and consolidated earnings, respectively, yields a value of $B$ which is positive, as hypothesized, but negligibly small and with t-statistic less than 0.1 . The results for the relationship based on after-tax earnings are aralogous.

In sum, the evidence does show substantial prevalence of the timing of pension contributions so as to smooth reported earnings, but it does not support the hypothesis relating this activity to the funding status of firms' pensions. The explanation for the underfunding puzzle apparently lies elsewhere. 
TABLE 8

RELATIONSHIP BETWEEN EARNINGS SMOOTHING AND PENSION FUNDING

\begin{tabular}{cc}
$\begin{array}{c}\text { Percentage Showing Smoother Reported } \\
\text { Than Consolidated Earnings }\end{array}$ \\
\hline Before Tax & After Tax \\
\hline 64.38 & 78.68 \\
50.0 & 66.7 \\
53.3 & 53.3 \\
69.0 & 66.7 \\
77.6 & 77.6 \\
73.6 & 75.7 \\
71.0 & 70.2 \\
69.8 & 70.6 \\
77.1 & 72.9 \\
58.6 & 60.6
\end{tabular}


IV. Pension Asset Allocations

Private pension plans invest their assets in a way unlike any other major category of institutional investors. For the aggregate of all pension plans, nearly two-thirds of all assets held are corporate equities. Among other major investor groups (apart from mutual funds), the corresponding fractions are about one-fifth equities for the public pension plans sponsored by state and local governments, one-sixth equities for fire and casualty insurance companies, and one-ninth equities for life insurance companies (even including some "separate accounts"). ${ }^{19}$ clearly there is something unique about the investment choices made by private pension plans. To the extent that the assets in a corporation's defined benefit pension plan "belong" to the sponsoring firm's shareholders, in the sense that they and not the plan's beneficiaries stand to gain or lose according to the assets' return, the heavy concentration of private pension assets in equities is not surprising. 20 By holding the corporation's shares in the first place, shareholders have already expressed the desire for an equity investment. Because of the pension plan(s) that the firm sponsors, however, each such investment represents ownership in two pools of assets. If the firm's pension plan holds debt securities instead of equities, then the shareholder's investment is no longer a pure (or even levered) equity but a mixture of debt and equity claims.

In the simplest abstraction like that used to motivate the discussion in section II, a corporation would not hold its pension assets in any form other than the ordinary assets of its business - that is, in its own stock. legal restrictions preclude holding pension assets entirely in this form, however, and also impose "prudence" standards that many firms interpret to preclude investing pension assets entirely in equity securities even on 
a fully diversified basis. Once again, therefore, the extreme simplification does not adequately describe the behavior of actual corporations and the pension plans that they sponsor. In addition, tax considerations appear to favor holding equity assets outside the pension plan and debt assets in the plan. 21

The discussion in section II emphasizes the role of the firm's pension assets and liabilities, along with the assets and liabilities on its balance sheet, in determining its overall risk and return posture. The allocation of the pension assets among alternative investment vehicles is a further element in this calculus. For example, borrowing in the credit market to finance additional (tax-deduction augmented) pension contributions has essentially no risk implications for the firm if the pension plan then invests these funds in debt securities, but such an action increases the firm's risk if the pension plan invests in equities. 22

The dependence of the firm's risk and return posture on the allocation of its pension assets raises in turn the possibility that these allocations may depend on the firm's asset-liability structure in the sense of either (1) or (2), or on other characteristics of the firm's business and financial situation as introduced in (3), or on both. Sharpe's analysis described in section II, for example, suggests that firms with nontrivial probability of bankruptcy have an incentive to maximize the value of the effective put to the PBGC. In the context of pension asset allocation decisions, therefore, the Sharpe hypothesis is that firms bearing greater overall risk will tend to invest their pension assets more in equities. Hence the more highly levered a firm is (as measured by debt on the balance sheet or by unfunded pension liabilities), or the greater is its risk exposure in other regards, the greater is the firm's 
incentive to invest its pension assets in equities.

In the simple context of (3), the question of pension asset allocation represents simply a disaggregation within the pension asset total PA. By contrast, if the total amount of pension assets is predetermined with respect to the allocation - as seems plausible in the context of most corporations' decision procedures - then PA is the constraining variable and the portfolio choice problem is of the form

$$
\frac{1}{\mathrm{PA}}\left|\begin{array}{c}
\mathrm{PA}_{1} \\
\mathrm{PA}_{2} \\
\cdot \\
\mathrm{PA}_{\mathrm{N}}
\end{array}\right|=\underline{\alpha}+\mathrm{BX}
$$

where the $P A_{i}$ are specific forms of pension assets, and $\underline{\alpha}$ and $B$ are again as in (3). Table 9 presents the results of estimating this relationship, for the sample of all Compustat firms sponsoring defined benefit plans, in the somewhat different form

$$
\frac{1}{B A}\left|\begin{array}{l}
P A E \\
P A D \\
P A O
\end{array}\right|=\underline{\alpha}+\underline{Y A} \frac{P A}{B A}+B X
$$

where $P A E, P A D$ and $P A O$ are pension assets in defined benefit plans, held in equities, debt securities, and other investment vehicles, respectively, $\underline{\alpha}$ is a vector of coefficients summing to zero, and $\underline{Y}$ is a vector of coefficients summing to unity.

The one result that stands out in Table 9 is the negative relationship between the allocation of pension assets to equities and the 


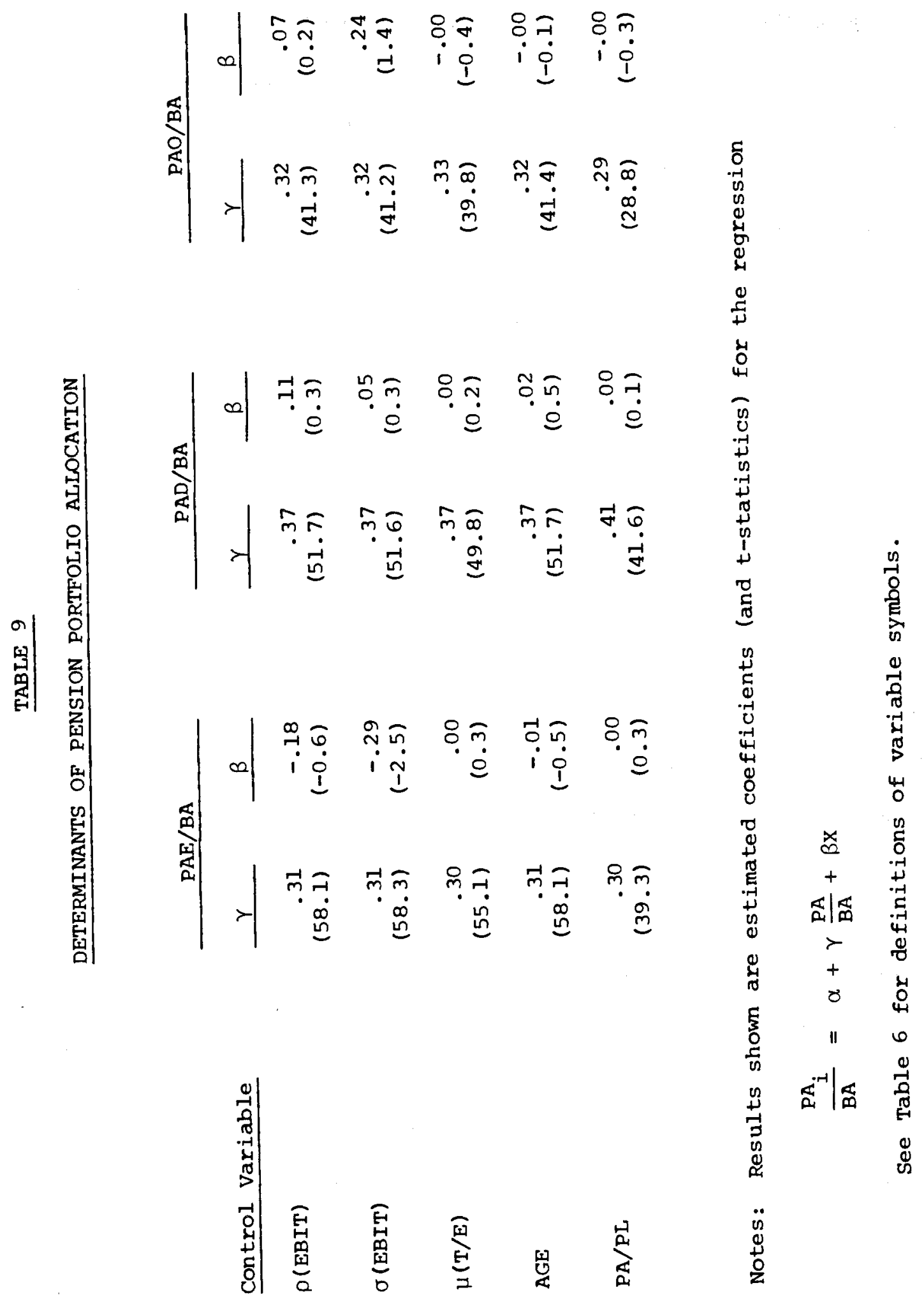


variability of the firm's earnings relative to trend - a result that is directly counter to the implication of Sharpe's hypothesis. Moreover, this result holds regardless of the definition of earnings used (before tax, after tax, with or without consolidation of pension contributions, etc.), and it also holds for subsamples limited according to the importance of pension assets in the firm's overall asset structure. ${ }^{23}$ Hence firms with greater business risk, as measured by greater volatility of earnings, systematically seek to offset at least part of that risk by investing their pension assets in instruments other than equities.

It is interesting that several measures included in Table 9 do not appear to affect pension asset allocations. Despite the incentives for taxable firms to hold high-yield assets in their pension plans and low-yield assets on their balance sheets, as emphasized by Black (1980) and Tepper (1981), the firm's tax status over the past five years had no apparent impact at this level. Similarly, although the age and related structure of the pension plan's beneficiary population affects the time profile of liabilities under the plan, the current employment ratio also had no effect. Finally, the firm's overall pension funding ratio had no noticeable effect either - again in apparent contradiction of Sharpe's analysis.

It is also useful to note how two specific aspects of the results shown in Table 9 carry over to the larger sample including Compustat firms' defined contribution plans as well as their defined benefit plans. First, the negative relationship between earnings volatility and the equity allocation was smaller in absolute magnitude, but statistically more significant, in the broader sample. ${ }^{24}$ with $\sigma$ (EBIT) as the control variable in (13), the 
estimated value of $\beta$ in the equity equation was -.11 , with t-statistic $-4.0\left(\bar{R}^{2}=.60\right)$. Second, although the current employment ratio of the beneficiary population did not matter in the defined-benefit-only sample, it did in the broader sample. With AGE as the control variable, the estimated value of $\beta$ in the equity equation was .014, with t-statistic $2.1\left(\bar{R}^{2}=.60\right) .^{25}$ Because a large AGE ratio typically reflects a younger beneficiary population, a positive $\beta$ value means that plans with younger workers are typically more heavily invested in equities. Hence pension plans in which the beneficiaries stand to gain or lose according to the return on the plan's invested assets do take account of the beneficiary population's age structure in making asset allocation decisions, even though plans in which the firm's shareholders stand to gain or lose from the assets' return do not. 26

The pension asset allocation and the pension funding ratio are two major determinants of prospective risk and return for many firms. A third important element in the risk and return structure, of course, is the debt on the firm's balance sheet. The relationship among these several components raises the possibility, therefore, that the firm's allocation of its pension assets may also depend on its basic leverage. A relationship consistent with the risk-offsetting strategy reported above, for example, would be for highly levered firms to offset some of their leverage by holding debt securities in their defined benefit pension plans. 27 Alternatively, under either Sharpe's PBGC put hypothesis or some form of "general aggressiveness" hypothesis, firms content to have a more leveraged position, as indicated by the liabilities on their balance sheets, might further extend that risk posture by investing their pension assets in equities. 
Table 10 presents the results of an attempt to examine this question in compact form by estimating the regression

$$
\frac{\mathrm{PAD}}{\mathrm{PAD}+\mathrm{PAE}}=\alpha+\gamma \frac{\mathrm{BL}}{\mathrm{BL}+\mathrm{BEQ}}+\beta \mathrm{X}
$$

where $B E Q$ is the book value of equity on the firm's balance sheet, and all other variables are as before. The estimated value of $\gamma$ is consistently positive, in contradiction to either the Sharpe hypothesis or a "general aggressiveness" hypothesis, indicating instead that firms with more highly levered balance sheets have some tendency to offset that leverage by investing more or their pension assets in debt securities. ${ }^{28}$ somewhat surprisingly, however, this positive relationship is statistically significant (and larger) in the broader sample including defined contribution plans but not in the sample limited to defined benefit plans. The estimated $\beta$ values shown in Table 10 support and extend the findings shown in Table 9 in several ways. First, the allocation of pension assets to debt securities is positively related to any measure of the variability of earnings. It is interesting that this effect, too, is always larger and more highly significant in the broader sample. second, firms with high rates of return (to either assets or book equity) tend to invest their pension assets more in equities and less in debt securities. Third, the firm's tax status apparently has no independent impact on pension asset allocation, although allowing for it about doubles the estimated magnitude of the effect of balance sheet leverage. Fourth, after allowance for balance sheet leverage, firms with younger pension beneficiary populations tend to invest more in debt securities and less in equities, although the estimated effect is smaller (as would be expected) and statistically insignificant 
Defined Benefit Only

Control Variable

$\rho(E B I T)$

$\sigma(E B I T)$

$\mu(\mathrm{E} / \mathrm{BA})$

$\sigma(\mathrm{E} / \mathrm{BA})$

$\mu(\mathrm{E} / \mathrm{EQ})$

$\sigma(E / E Q)$

$\mu(T / E)$

AGE

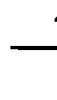

$\gamma$

(0.9)

.05

(1.1)

.02

$(0.4)$

.05

(1.1)

.04

$(0.7)$

.04

$(0.8)$

.10

$(2.0)$

.05

(1.0)

$B$
-.23
$(-0.3)$
1.31
$(3.6)$
-.25
$(-0.8)$

1.77

(3.8)

$-.08$

$(-2.1)$

.03

(1.9)

.00

$(0.5)$

.22

$(2.6)$
All Pension Plans

\begin{tabular}{|c|c|}
\hline$\gamma$ & $B$ \\
\hline $\begin{array}{r}.09 \\
(1.9)\end{array}$ & $\begin{array}{r}.07 \\
(0.1)\end{array}$ \\
\hline
\end{tabular}

.09

1.86

$(2.0)$

$(5.7)$

.02

$-.55$

$(0.4)$

$(-1.9)$

.09

2.96

$(2.0)$

(6.9)

.07
$(1.5)$

$-.11$

$(-2.6)$

.07

.04

1.6)

(2.3)

.17

(3.8)

.00

$(0.4)$

$\left(\begin{array}{c}.08 \\ (1.9)\end{array}\right.$

.14

(1.8)

Notes: Results shown are estimated coefficients (and t-statistics) for the regression

$$
\frac{P A D}{P A D+P A E}=\alpha+\gamma \frac{B L}{B L+B E Q}+B X
$$

$E / E Q \quad=$ ratio of earnings to book value of equity

$\mu(E / E Q)=$ ten-year mean of $E / E Q$

$\sigma(E / E Q)=$ ten-year standard deviation of $E / E Q$ around $\mu(E / E Q)$

See Table 6 for definitions of other variable symbols. 
in the broader sample including defined contribution plans.

The main conclusions of this analysis of the allocation of pension assets, on the assumption that not only the pension asset total but also the other principal elements of the firm's asset and liability structure are predetermined with respect to that allocation choice, are (1) that firms with more volatile earnings invest pension assets so as to offset their ordinary business risk by holding less equity and more debt securities in the pension; (2) that firms with more highly leveraged balance sheets invest pension assets so as to offset this risk too, again by holding less equity and more debt securities in the pension; (3) that firms earning high rates of return adopt the opposite allocation strategy, investing pension assets more in equities and less in debt securities; and (4) that firms' pension asset allocation decisions also depend on the current employment status of the pension beneficiary population, with employed (hence presumably younger) beneficiaries leading firms with defined benefit plans to invest pension assets less in equity and more in debt securities, but with just the opposite effect for defined contribution plans. 


\section{The Corporate Balance Sheet}

The empirical analysis undertaken in Sections II and IV considers first the firm's pension funding strategy, and then its pension asset allocation, on the assumption that the amount and nature of assets and liabilities on the firm's balance sheet are predetermined with respect to decisions about the firm's pension. Such a secondary role for pension decisions in corporate financial structures may be plausible when the sums involved are small in relation to the sponsoring firm's ordinary business assets and liabilities. In an increasing number of corporations, however, pension liabilities (and pension assets too, if the liabilities are fully funded) are large in comparison to the assets and liabilities that appear on the firm's balance sheet. Moreover, pensions are continuing to grow more rapidly than general corporate assets or liabilities. The larger pensions become, the more likely it is that firms make decisions about their pension assets and liabilities and their other assets and liabilities jointly.

As the discussion in Section II already emphasizes, the combination of legal requirements and established labor market practices sharply restricts many firms' flexibility with respect to their pension liabilities. In considering possible interrelationships by which the firm's pension assets and liabilities affect its ordinary business decisions, therefore, a useful place to begin is the possibility that the direction of influence in (4) and (5) is backward. Estimating the reverse relationship, in which the firm takes its pension liabilities as given in deciding how much to borrow on its balance sheet,

$$
\frac{B L}{N W}=\alpha+\gamma \frac{P L}{N W}
$$


yields $\gamma=.26$, with t-statistic $7.8\left(\bar{R}^{2}=.04\right)$, for the sample of all Compustat firms sponsoring defined benefit plans, and $\gamma=.34$, with t-statistic $7.9\left(\bar{R}^{2}=.17\right)$ for the subsample in which each firm's pension liabilities equal at least one-tenth of its total assets. 29

That estimating (4) in the reverse order (15) again leads to a significant positive relationship is hardly surprising. What is more interesting is that the positive partial relationship between pension liabilities and other liabilities - that is, the relationship after allowance for other controlling variables - also holds up on reversal of the ordering. Table 11 presents results, analogous to those in Table 6 , of estimating the reverse of (5),

$$
\frac{B L}{N W}=\alpha+\gamma \frac{P L}{N W}+B x
$$

for the full sample and the sample with $P L / T A \geq .10$. conce again, the strong positive value of $\gamma$ appears regardless of the choice of controlling variables.

Although the focus of this paper is not on corporations' debt issuance, except in its relation to their sponsored pension plans, it is interesting nevertheless to notice several of the $B$ values in Table 11 . First, the growth of earnings had no effect on pension liabilities in (5), but earnings growth negatively affects other liabilities in (16). This result also holds for other definitions of earnings. Second, the mean rate of return either on assets or on equity (not shown in the table) had no effect on pension liabilities in (5), but mean returns negatively affect other liabilities in (16). Third, the variability of the firm's rate of return affected pension liabilities negatively in (5), but return variability affects other liabilities positively in (16), at least in the full sample. ${ }^{30}$ Fourth, 
Full Sample

\begin{tabular}{|c|c|c|}
\hline Control Variable & $\gamma$ & B \\
\hline$\rho(E B I T)$ & $\begin{array}{r}.25 \\
(7.5)\end{array}$ & $\begin{array}{l}-5.62 \\
(-6.5)\end{array}$ \\
\hline$\sigma(E B I T)$ & $\begin{array}{r}.26 \\
(7.5)\end{array}$ & $\begin{array}{r}.40 \\
(1.0)\end{array}$ \\
\hline$E / B A$ & $\begin{array}{r}.22 \\
(6.9)\end{array}$ & $\begin{array}{r}-3.52 \\
(-20.6)\end{array}$ \\
\hline$\mu(E / B A)$ & $\begin{array}{r}.20 \\
(5.6)\end{array}$ & $\begin{array}{r}-4.11 \\
(-15.5)\end{array}$ \\
\hline$\sigma(E / B A)$ & $\begin{array}{r}.24 \\
(6.1)\end{array}$ & $\begin{array}{r}1.20 \\
(2.3)\end{array}$ \\
\hline$\mu(T / E)$ & $\begin{array}{r}.24 \\
(6.5)\end{array}$ & $\begin{array}{r}.00 \\
(0.1)\end{array}$ \\
\hline$\mu(L / S)$ & $\begin{array}{r}.28 \\
(5.6)\end{array}$ & $\begin{array}{r}-.33 \\
(-2.4)\end{array}$ \\
\hline AGE & $\begin{array}{r}.24 \\
(6.1)\end{array}$ & $\begin{array}{r}.12 \\
(1.2)\end{array}$ \\
\hline
\end{tabular}

$\underline{\text { PL/TA } \geq .10 \text { Subsample }}$

\begin{tabular}{|c|c|}
\hline$\gamma$ & $B$ \\
\hline $\begin{array}{r}.32 \\
(7.6)\end{array}$ & $\begin{array}{l}-8.45 \\
(-4.0)\end{array}$ \\
\hline $\begin{array}{r}.34 \\
(7.9)\end{array}$ & $\begin{array}{r}-.92 \\
(-1.0)\end{array}$ \\
\hline $\begin{array}{r}.28 \\
(6.8)\end{array}$ & $\begin{array}{r}-3.77 \\
(-11.1)\end{array}$ \\
\hline
\end{tabular}

$\begin{array}{rr}.27 & -4.66 \\ (6.0) & (-8.6)\end{array}$

$.34 \quad 1.54$

(6.8) (1.1)

$\begin{array}{lr}.33 & -.02 \\ (6.9) & (-0.5)\end{array}$

$\begin{array}{rr}.30 & -.63 \\ (5.7) & (-2.5)\end{array}$

$.33--.28$

$(6.6) \quad(-1.5)$

Notes: Results shown are estimated coefficients (and t-statistics) for the regression

$$
\frac{B L}{N W}=\alpha+\gamma \frac{P L}{N W}+B X
$$

See Table 6 for definitions of variable symbols. 
labor intensity affected pension liabilities positively in (5), at least in the full sample, but labor intensity affects other liabilities negatively in (16). Each of these influences is familiar in the literature on corporate choice of capital structures, and these results would perhaps be of interest in an investigation of that subject. In the context of this paper's focus on pensions, the main point is simply that the positive partial relationship between pension liabilities and other liabilities holds up after allowance for any of these separate effects. Similar conclusions follow from reversing the order of (7) and (8), which treat not total pension liabilities but only the unfunded portion as the relevant measure. Estimating the reverse relationship

$$
\frac{\mathrm{BL}}{\mathrm{NW}}=\alpha+\gamma \frac{\mathrm{PL}-\mathrm{PA}}{\mathrm{NW}}
$$

yields $\gamma=.50$ with t-statistic $10.1\left(\bar{R}^{2}=.07\right)$, for the full sample and $\gamma=.61$, with t-statistic $10.8\left(\bar{R}^{2}=.27\right)$ for the PL/TA $\geq .10$ subsample. ${ }^{31}$ Controlling for additional influences by estimating the regression

$$
\frac{B L}{N W}=\alpha+\gamma \frac{P L-P A}{N W}+\beta X
$$

also yields consistently positive $\gamma$ values, and $B$ values roughly in line with those shown in Table 11 and discussed above.

once again, it is useful to examine whether pension liabilities and assets matter separately in this context, or whether what matters is only the difference, as in (17) and (18). Estimating the regression

$$
\frac{B L}{N W}=\alpha+\gamma \frac{P L}{N W}+\delta \frac{P A}{N W}
$$


for the full sample yields $\gamma=.49$ and $\delta=-.51$ with respective $t$-statistics 4.8 and $-2.7\left(\bar{R}^{2}=.05\right)$. For the $\mathrm{PJ} / \mathrm{TA} \geq .10$ sample, the corresponding results are $\gamma=.58$ and $\delta=-.54$, with respective t-statistics 6.1 and -3.1 $\left(\bar{R}^{2}=.17\right)$. To the extent that firms make borrowing decisions in light of their pension assets and liabilities, therefore, what matters is just the unfunded pension liabilities. ${ }^{32}$ Moreover, these results too hold up in the presence of other controlling variables like those included in Table 10.

Finally, if firms decide on their pension assets and liabilities and on their other assets and liabilities in a fully joint way, then neither the direction of influence assumed in the regressions presented in Section II nor that assumed in (15) - (19) is strictly correct. Instead, a fully simultaneous portfolio choice like that in (3) - or, if only unfunded pension liabilities matter, (6) - would be the correct way to view the firm's decision process. Table 12 presents results (values of $\beta$ ) for estimating (3) directly, using one independent variable at a time. These results add little to the analysis above, however. With the somewhat marginal exception of the earnings volatility measure, the estimation of the full portfolio choice model does not reveal influences that affect both the pension and the balance sheet. 33

The main conclusions of this analysis of the relationship between the firm's borrowing decisions and its pension assets and liabilities are (1) that the amount of liabilities on the firm's balance sheet is positively related to the firm's pension liabilities; and (2) that what matters for the determination of balance sheet liabilities in this context is just the firm's unfunded pension liabilities rather than its pension assets and liabilities separately. 


\begin{tabular}{|c|c|c|c|c|}
\hline Control Variable & $\frac{B L}{N W}$ & $\frac{\mathrm{BA}}{\mathrm{NW}}$ & $\frac{P L}{N W}$ & $\frac{P A}{N W}$ \\
\hline$\rho($ EBIT) & $\begin{array}{l}-7.32 \\
(-5.5)\end{array}$ & $\begin{array}{l}-8.26 \\
(-5.2)\end{array}$ & $\begin{array}{l}-1.15 \\
(-1.0)\end{array}$ & $\begin{array}{r}-.21 \\
(-0.3)\end{array}$ \\
\hline$\sigma(\mathrm{EBIT})$ & $\begin{array}{r}.91 \\
(1.6)\end{array}$ & $\begin{array}{l}1.63 \\
(2.5)\end{array}$ & $\begin{array}{r}1.45 \\
(2.9)\end{array}$ & $\begin{array}{r}.72 \\
(2.7)\end{array}$ \\
\hline $\mathrm{E} / \mathrm{BA}$ & $\begin{array}{r}-4.10 \\
(-16.8)\end{array}$ & $\begin{array}{r}-4.42 \\
(-14.0)\end{array}$ & $\begin{array}{l}-0.23 \\
(-0.8)\end{array}$ & $\begin{array}{r}0.08 \\
(0.5)\end{array}$ \\
\hline$\mu(E / B A)$ & $\begin{array}{r}-4.94 \\
(-12.7)\end{array}$ & $\begin{array}{r}-5.42 \\
(-11.1)\end{array}$ & $\begin{array}{r}-.62 \\
(-1.5)\end{array}$ & $\begin{array}{r}-.14 \\
(-0.6)\end{array}$ \\
\hline$\sigma(E / B A)$ & $\begin{array}{r}2.21 \\
(2.8)\end{array}$ & $\begin{array}{l}-2.16 \\
(-2.2)\end{array}$ & $\begin{array}{r}-.46 \\
(-0.6)\end{array}$ & $\begin{array}{r}-.41 \\
(-1.0)\end{array}$ \\
\hline$\mu(T / E)$ & $\begin{array}{r}-.01 \\
(-0.5)\end{array}$ & $\begin{array}{r}-.01 \\
(-0.4)\end{array}$ & $\begin{array}{r}-.00 \\
(-0.1)\end{array}$ & $\begin{array}{r}-.00 \\
(-0.2)\end{array}$ \\
\hline$\mu(I / S)$ & $\begin{array}{r}-.08 \\
(-0.4)\end{array}$ & $\begin{array}{r}.22 \\
(1.0)\end{array}$ & $\begin{array}{r}.74 \\
(4.7)\end{array}$ & $\begin{array}{r}.45 \\
(5.1)\end{array}$ \\
\hline AGE & $(0.9)$ & $\begin{array}{r}-.28 \\
(-1.6)\end{array}$ & $\begin{array}{c}-.68 \\
(-5.2)\end{array}$ & $\begin{array}{r}-.28 \\
(-3.8)\end{array}$ \\
\hline
\end{tabular}

Notes: Results shown are estimated coefficients (and t-statistics) for the regression

$$
\frac{1}{N W}\left|\begin{array}{l}
B L \\
B A \\
P L \\
P A
\end{array}\right|=\alpha+\underline{X} \underline{B}
$$

See Table 6 for definitions of variable symbols. 
VI. Concluding Remarks

The final paragraph in each of sections II - V summarizes in capsule form the principal specific empirical findings of this paper, and there is no need to restate each one here. The unifying overall conclusion from the data is that U.S. corporations do not manage the pension plans which they sponsor as if these plans had nothing to do with the corporation. Different responses appear to characterize firms' behavior in different contexts, but the evidence persistently indicates clear relationships between decisions about pension assets and liabilities and decisions about the other assets and liabilities of the firm. At the same time, the pattern of these relationships is, more often than not, inconsistent with familiar hypotheses that have emerged thus far in the theoretical literature analyzing pension aspects of corporate finance.

At least three caveats are important, however. The most significant is that the measurement of pension liabilities is hardly uniform across firms. To the extent that each corporation's management believes that the value it reports for liabilities on Form 5500 schedule $B$ is the best available measure of the firm's actual commitment or exposure, firm-tofirm variation in actuarial assumptions need not affect the analysis here. If managements make allowance for the differing actuarial assumptions, however, then this analysis neglects a potentially important element. ${ }^{34}$ Further potential problems of a related nature also arise in connection with the date and the method chosen for schedule $B$ valuation of pension assets. The second major caveat stems from the use in this paper of fully consolidated firm data, incorporating all wholly owned subsidiaries, whenever possible. No doubt many parent corporations do adopt a consolidated approach to financial management. Even so, the possibility remains that many 
firms handle such matters as pension decisions in a decentralized way, or that some of the parent-subsidiary relationships consolidated here were then (and may still be) too recent to have had much impact on the structure of the subsidiaries' pension assets and liabilities.

The third reason for caution in interpreting the results presented here is simply that they reflect evidence from a cross-section of firms (a quite comprehensive cross-section, to be sure) in one year only. Despite its portfolio-theoretic approach, therefore, the analysis entirely omits any account of effects due to changing yield relationships over time. For the same reason, the analysis is also subject to all of the usual problems associated with observing only one point in time. Was 1977 a "typical" year, in any or all of the many senses that matter here? It is never possible to answer such a question adequately. At the least, however, the Employee Retirement Income Security Act and the Pension Benefit Guarantee Corporation were both very recent as of 1977, and neither may yet have had its full impact on corporations' behavior.

Each of these three reservations about the analysis presented in this paper points to potentially fruitful directions for further empirical research. Taking account of cross-firm variation in pension actuarial decisions, more carefully treating the range of possible parent-subsidiary relationships, and working with additional data as it becomes available would all be major extensions of this work which could importantly alter the conclusions reached. No doubt additional lines of investigation would provide new insights also. This paper only begins to analyze the interrelationships connecting private pensions and corporate finance. As private pensions continue to grow, in both absolute and relative terms, those interrelationships will almost surely become more powerful and more important for understanding financial behavior. 


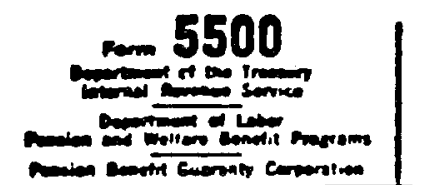

\section{Aanual Retura/Repert of Employee Denefit Plan (Mith 100 or more participants)}

This form th required to be filod under wextions 104 ond 4065 of the Emplopos Retirument income security Act of 1974 and exctionis $6057(b)$

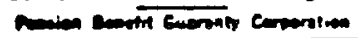
and Coseia) of the Intemal Rewenu Code, neferred to as the Code.

for we calender dice reat 1917 or fiscal plan yest betinsing .1971 and onding

Fits ericinal of thin form, including schedules and attechmenta, completed in irith or type.

Koogh (H.R. 10) plans with tewer than 100 participants and with at hast one owner employee participant do ned his this borm. File form 5500-K instead.

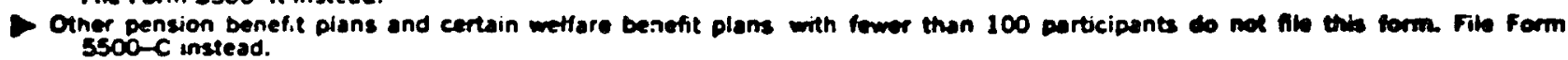

Wellars benetit plans with 100 or more participants complete only items 1 through 16 and item 22.

- Pansion beneft plans, unless othermise excepted. complete all rems. Annuity arrangements of cortain examot arganizations and indrudual returement account tusts of empioyers complete only items 1 through 6. 9 and 10.

- Covemment plans and church plans (not electing coverage under section 410(d) of the Code) complete only items 1 through 7. 9. 10(a). (b). (c). (d). 11 and 17.

- Thion number-Your 3 digit plan number must be entered in item $5(c)$ : see instruction $5(c)$ for explanation of colan number." 2 II eny item does not apply. enter "N/A."

I (a) Name of plan sponsor (employer if for a engle erriployer plian)

\begin{tabular}{|c|c|}
\hline Address (number and sureat) & $\begin{array}{l}\text { I (c) Telephome number of sponser } \\
(\text {, ) }\end{array}$ \\
\hline \multirow{2}{*}{ City or town, state and ZIP code } & 2 (d) Employer taxuble yar ends \\
\hline & Day Vear 19 \\
\hline (d) Name of plan administrator (if other than plan sponsor) & I (o) Businase code number \\
\hline Address (number and street) & 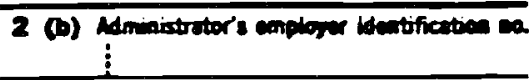 \\
\hline City or trown, State and ZIP coode & 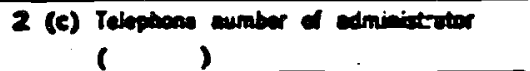 \\
\hline
\end{tabular}

3 Name. address and dentification number of $\square$ plan sponsor and/or $\square$ plan administratior as they apparred en the last retum/ seport filed tor this plan if not the same as in 1 or 2 atowe

4 Check appropriate box to indicate the type of plan entity (check only one box):
(a) $\square$ single-employer plan
(c) $\square$ Murtuemplojer plon
(b) $\square$ Plan of controlled group of corporstions (d) $\square$ Multiple-employer-collec.
or common control employers
tivety-as rgained plan
(o) $\square$ Multiple-employer plan (other)
(1) $\square$ Group insurance arrangement (of

$S$ (a) (i) Name of plan

(ii) $\square$ Check if changed since last return/report

5 (b) Effective date of plan

5 (e) Enter three digit Dlan number -

6 Check at least one item in (a) or (b) and applieable items in (c). Item (d) on page 2 must be completed:
(a) Welfare benefit plan:
(i) $\square$ Hearth insurance
(i) $\square$ Lfo insurance
(iii) $\square$ supplemental unemployments

(iv) $\square$ Other (specity)

(b) Pension benefit plan:

(1) Defined benefit plan-(indicate type of defined benefit plan below):
(A) $\square$ Fured benefie
(B) $\square$ Unit beriefit
(C) $\square$ Fiat benefit
(D) $\square$ Other (epecity) -

(i) Defined contribution plan-(indicate type c: defined contribution plan below):
(W) Profitsharing
(B) $\square$ Stock bonus
(C) $\square$ Target benefit
(D)
Ouner monoy purchase

(iii) $\square$ Defined benefit plan with benefits based partiy on balance of separate ercount of participant (section $414(k)$ of the Code)

(w) $\square$ Annuity serrangement of a certain exempt organization (section $403(b)(1)$ of the Code)

(v) $\square$ Custodial account for regulated imvestment company stock (section $403(b)(7)$ of the Code)

(m) $\square$ Trust treated as an individual retirement account (section $408(c)$ of tha Codo)

(vi) $\square$ Employee stock ownership plan not part of a qualified plan (section 301 (d) of the Tax Reduction Act of 1975)

(vii) $\square$ other (specity) -

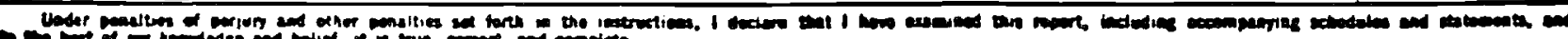

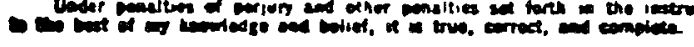




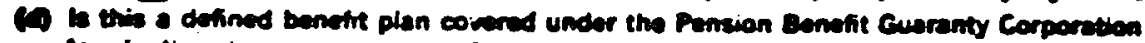

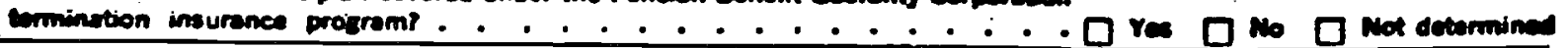

7 Mumbar of participanta as of the end of the plan yaur (wolfare obens complece anty (o)(w). (b), (c) and (d)): (1) Active particionts (omployed or cartiod as active) (1) Number fully waled . .

(i) Number artielly weated.

(ii) Number nomeated. .

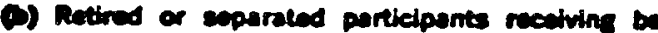

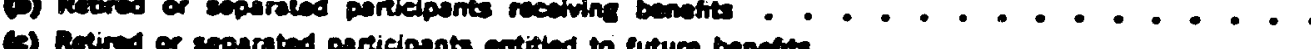

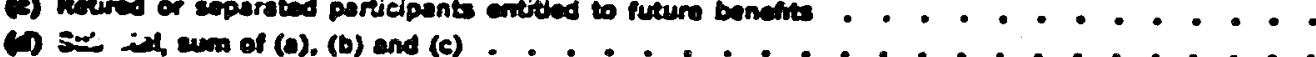

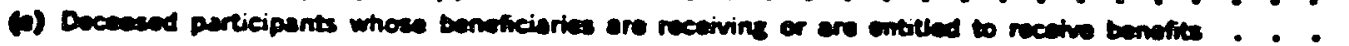

of Total (d) phe (.) . . . . . . . . . . . . . . . . . . . . . .

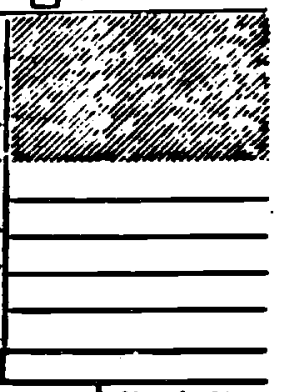

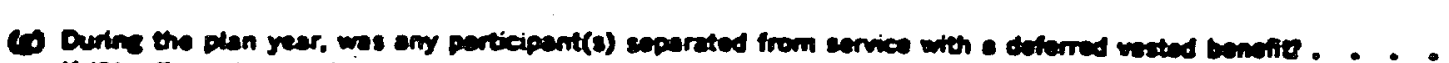
II YYe "

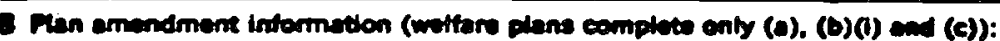

(1) Wes eny amondment to this plan edopted in this plen yeart. . . . . . . . . . . . .

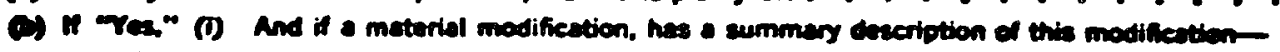

(A) Eeen sent to plan perticipantal ...............

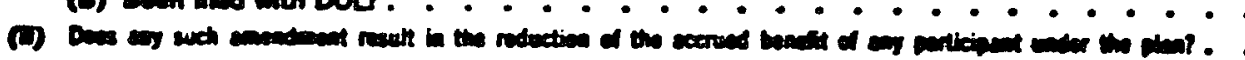

(9) Writ emendmont resut in a reduction of curvent or futurs beneficas.

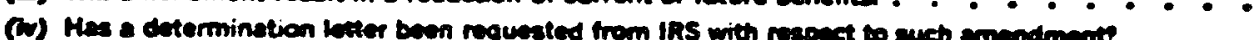

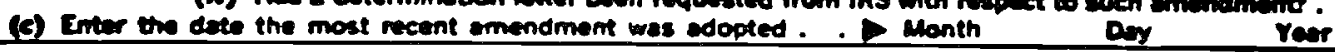

- Fan termination information (welfere plans complete only (a). (b). (c) and (n):

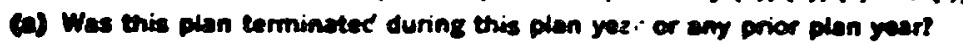

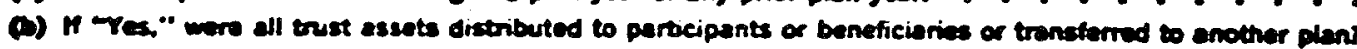

(C) Was a reolution to terminate this plan adopted during this pion vear or any prior plan went

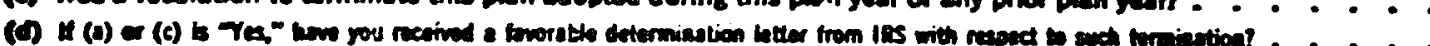

(D) $M(d)$ is "Na," has o determination ketter been requested from IASP . . . . . . . . . . . . . . . .

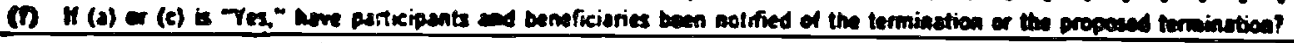

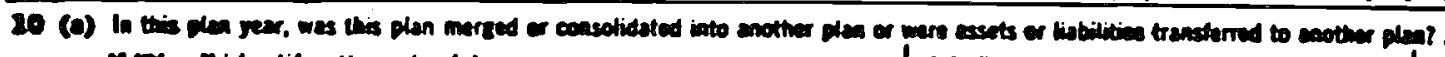

if rese identify other plan(s):

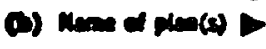

(c) Employer identifiention number(s)

(d) Pun number(s)

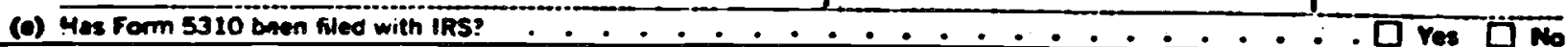

II Indicate funding arrangement

6) $\square$ Trust (oentits provided in whols trom truse hunds)

a) $\square$ Trux or arrangement providine benefits partially through imurence end/or ennulty contrects

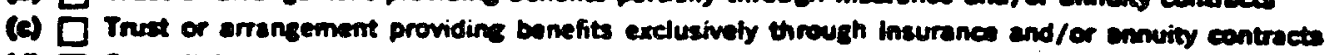

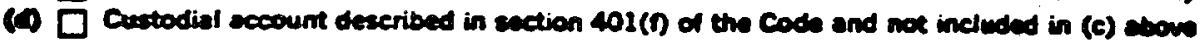

(4) 0 Other (epocily) -

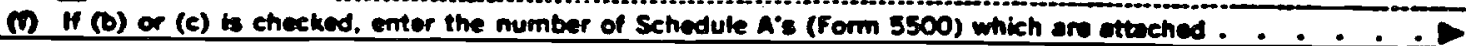

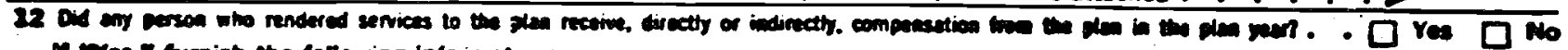
A qes, fumieh the following informateon:

L)


2 man ossets and habilities at the beginning snd the and of the plen vear (ligt all assets and liabilities at current value). If plan b unded entirety by allocated insurance contracts for which no trust binvohed, chech box and do not complete this item. .

neter include all plan essets and liabilities of a trust or separately maintained fund. (II more than ane trust/fund. report on a combuned bssis.) Include unallocoted, but not allocated, insurance contracts. Round off amounts to nasrest joller.

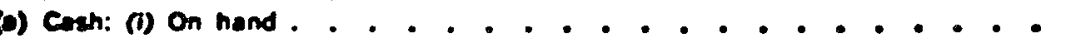

(W) In bank (A) Certificates of deposit. . . . . . . . . . . . .

(B) Orher Interata baring . . . . . . . . . . . . . . .

(C) Moninterest baring . . . . . . . ............

(iij) Total cash

(b) Recervables: (i) Employe contmbutions

(d) Employe contribution

(ii) Other.

(b) Reserve for doubtul sccounts

(v) Net recoivades, sum of (i). (ii) and (ii) minus (b)

(a) Ceneral imvestments other than party-in-interext imvesmenter

(D) U.S Covemment securitios:

(A) Lon thm

(a) Short term .

(i) Corporate debt instrumenta:

(A) Long term . . . . . . . . . . . . . . . . . .

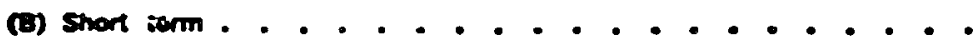

(w) Corporate stocks: (A) Proferred . . . . . . . . . . . . . .

(B) Commen . . . . . . . . . . . . . . .

(v) Shares of a registered imvestment company . . . . . . . . . . .

(w) Red estat . . . . . . . . . . . . . . . . . . . . .

(vii) Mortgages . . . . . . . . . . . . . . . . . . . . . .

(vii) Lams orher than mortgages . . . . . . . . . . . . . . . .

(bx) Value of interest in pooled fund(s) . . . . . . . . . . . . . .

(a) Other imestments . . . . . . . . . . . . . . . . .

(xi) Total eeneral imvestments, sum of (i) through (x) . . . . . . . .

(d) Porty-in-interest investments:

(i) Corporate debt instruments .

(i) Comporse stocks: (A) Preferred.

(a) Common

(ii) Ral rimte

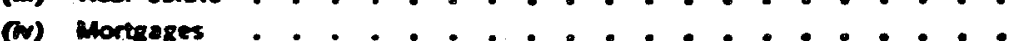

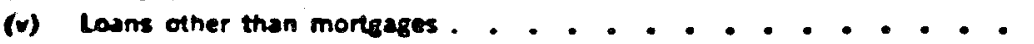

(vi) Other imestments . . . . . . . . . . . . . . . . . .

(vii) Tobl party.in.interest imvestments, sum of (i) through (vi) . . . . . . .

(e) Buldings and other vepreciable property

(i) Value of unallocated insurance contrects:

(i) Separate accoumts . . . . . . . . . . . . . . . .

(ii) Ocher . . . . . . . . . . . . . . . . . . .

(iii) Totol. (i) plus (ii) . . . . . . . . . . . . . . . . . .

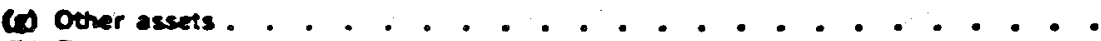

(h) Total assets, wm of (o)(ii), (b)(v). (c)(ni), (d)(vii), (e). M(iii) and (s). uniniting

a) Probles: (i) Pun claims . . . . . . . . . . . . . . . . . . .

(W) Other paybles . . . . . . . . . . . . . . . . . . .

(iii) Total pryables, (i) plus (ii) ......................

(1) Acquisition indebtedness . . . . . . . . . . . . . . . . . .

(W) Other liabilities. . . . . . . . . . . . . . . . . . . . . .

(I) Total liabilities, sum of (i)(iii). (d) and (k).

(im) Net assets. (h) lese (1)

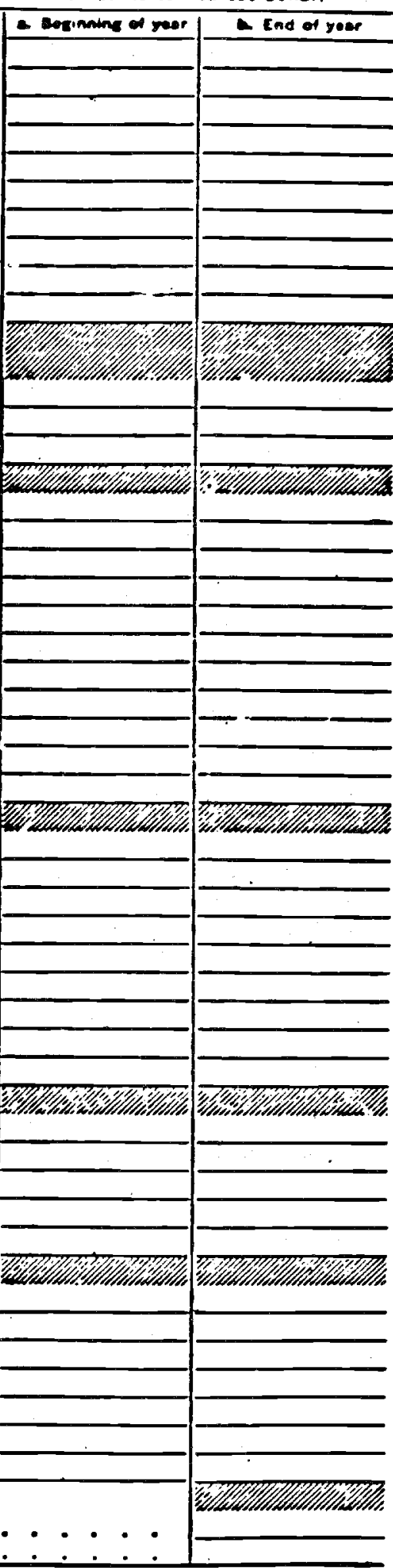

(i) Tocal cost of scquisitions for common stocks .

(ii) Total proceeds from dispoutions of eommon tocia 
I4 Plan income, expenses and changes in not assets for the plan year:

Noce. Include all income and expenses of o trust(s) or soperefely maintained tund(s). Round ofl emounts to ineanest dollar.

(4) Contributions received or mecivable in cash trom-

(I) Employer(s) (including contributions on bahalf of seffemployed individuals)

(W) Emplogres . . . . . . . . . . . . . . . .

(i) Others . . . . . . . . . . . . . . . . . . .

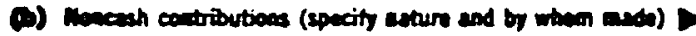

(c) Total contribution, sum of (o) and (b) ................

(d) Eamings trom investments-

(I) Intere . . . . . . . . . . . . . . . . .

(i) Dividands . . . . . . . . . . . . . . . . .

(iii) Rents. . . . . . . . . . . . . . . . . . .

(v) Royaries. . . . . . . . . . . . . . . . . . .

(0) Net realized gain (tose) on sale or exchange of assets-

(I) Alepi iepto proconds . . . . . . . . . . . . . . .

(I) Aarreatu conts. . . . . . . . . . . . . . . . . . . .

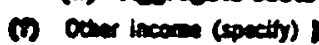

(o) Total income, sum of (c) through (n) Exponises

a) Distribution of bennfits and payments to provide benefite-

(1) Directy to participants or their benefieiaries . . . . . . . . .

(I) To insurance carrier or similar orzanization for provision of benefits. . -

(ii) To other orgerizations or individuals providing weffare benefit . . . . :

D) Interest expense . . . . . . . . . . . . . . . . . . . .

(1) Administrative expenses-

(i) Salaries and allownances . . . . . . . . . . . . . .

(ii) Fees and commissions . . . . . . . . . . . . . .

(iii) Insurance premiums for Pension Benefit Guaranty Corporation . . . . .

(iv) insuranse premiums for fiduciary insc-ance other then bonding . . . . .

(v) Other administrative expenses . . . . . . . . . . . . . .

(W) Other axpenses (specity)

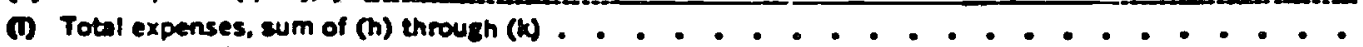

(m) Net income (expenses). (g) minus (I)

(n) Crange in net assets-

(i) Unrealized appreciation (depreciation) of assets . . . . . . .

(ii) Other changes (specity) -

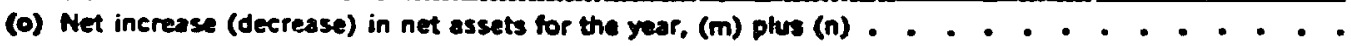

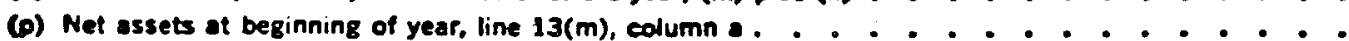

(q) Net assets at end of year, $(0)$ plus $(p)$ (equals lime $13(\mathrm{~m})$, column $b) . . . . . . . . . . . .$.
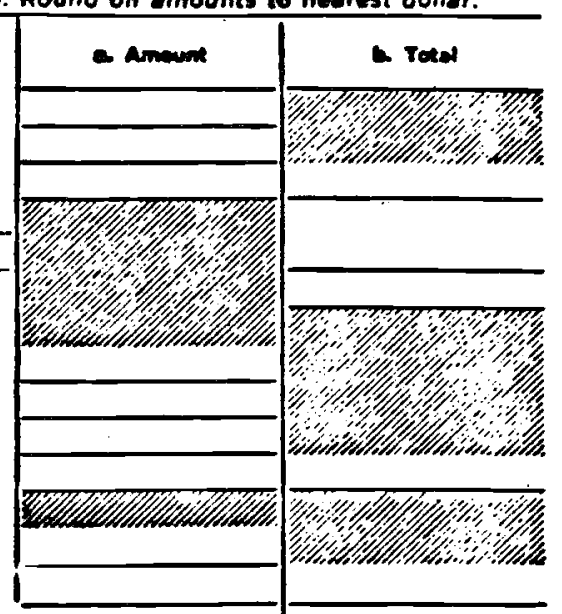

Is Has there been any change since the last report in tho appointment of any trustee, accountant, insurance carrier. enrolled actuary, administrator, investment manager or custodien?

If "Yes." explain and include the name, position, address and telephone number of the individual who lett or was removed by the plan - 
(a) Was the plan insured by a fidelity bond aguinst beses through fraud or dishonestyl . . . . . . .

(b) If "Yes." enter the maximum amoumt of loss reoverable

(c) Enter the aume of the surety company

(d) Dos the plan, or a known party-intinterest with respact to the plan, haw any control or signifieamt financel interest direct or indirect in the survty company or its aconts or brokers . . . . . . . . . . . .

(0) If the plan is not insured by a fidelity bond, explain why not -

(1) In the current plan year was any lose to the plan caused by the fraud or dishonesty of any plan oficial or em. plogre of the plan or of other person handling funds of the plan? . . . . . . . . . . . . . . . If "Yes," see specific instructions.

27 information about employes of employer at and of the plan year (Finns not purporting to satisty the purcemtage tests of section $410(b)(1)(A)$ of the code complete onty (a) betow and see specific instructions):

(a) Total numbar of emplorves . . . . . . . . . . . . . . . . . . . . . . . .

(1) Number of employees excluded under the plan-

(I) Minkmum age or yars of anvic . . . . . . . . . . . . . . . . . . . . .

(D) Employes on whose bohalf retirement benefits wore the subject of collective bargaining. .

(iii) Nonresident atiens who receive no eamed income from United States sources . . . . . . .

(v) Toal excluded, sum of (i), (ii) and (ii) . . . . . . . . . . . . . . . . . .

(c) Tocal number of employess not excluded, (a) less (b)(iv) . . . . . . . . . . . . . .

(d) Employes ineligible (specity resen) -

(e) Enployes eligible to participate, (c) las (d) . . . . . . . . . . . . . . . . . .

(i) Emplorens eligibie but not participating . . . . . . . . . . . . . . . . . . .

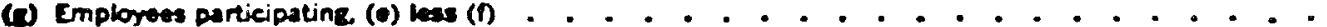

2 is this plan an adeption of a:

(a) $\square$ vaster/prototype,

(b) $\square$ Freld prototype.

(c) $\square$ Pattem or

(d) $\square$ Moded pian?

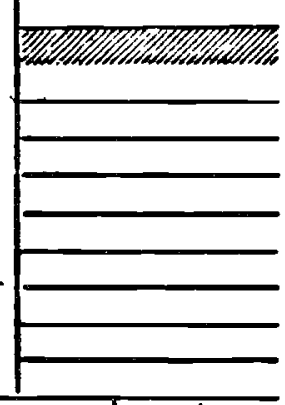

If 'Yes - enter the four or eight digit IRS serial number (see instructions) _

29 (a) Is it intended that this plan qualify under eection 401 (a) or 405 of the Code?

(b) Have you requesfed of received a determination letter from the IRS for this plan?

20 If plan is integrated, check appropriote box:

(e) $\square$ Sacial security

(b) $\square$ Roilrosd rotiroment

(c) $\square$ Oower

21 (a) Is this a delined benefit plan subject to the minimum funding standards for this plan yas? If "Yes," attach Schedula $\mathrm{B}$ (Form 5500).

(1) It this defined contribution plan, Le, mony purchase or earget benefit, subject to the minimum tunding standirdst (If a waiver was granted, see instuctions.) . . . . . . . . . . . . . . . . . . If "res," complete (I), (ii) and (ii) below:

(I) Amount of employer contribution required for the plan year under section 412 of the code.

(ii) Amount of contribution poid by the employer for the plan yer . . . . . . . . . . . Enter date of last payment by employer. . . . . Month Dey Yer

(iii) Funding deficiency ercess, if eny of (i) over (ii)

2 The foltowing questions relate to the plan sear. If (a)(i), (ii), (iii), (iv) or (v) is checked wes," schedules of such items in the format set forth in the instructions are required to be attached to this form.

(a) (i) Did the plan have essets hetd for imestment?

(ii) Did any non-exempt transaction invotving plan asects involve party knom to os party in-interest?

(iii) Wers any bans by the plan or fixed income obligations due the plan in defaut as of the close of the plan year or classified during the year as uncollectable? . . . . . . . . . . . . . . . . . .

(v) Were any leases to which the plan was a party in defaut or classified during the year as uncollectable?

(v) Were ary plan transactions or series of transactions in excess of $3 \%$ of the current value of plan assets? .

(B) The eccountant: opinion is $\square$ not required or $\square$ required, attached to this form, and is-

(i) $\square$ Unqualified

(H) $\square$ Qualified

(iii) $\square$ Adverse

(h. $\square$ Other (explein)

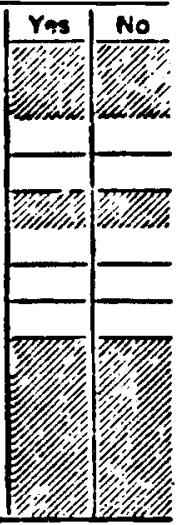




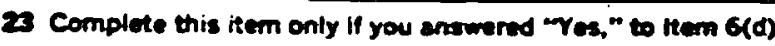

Did one or more of the reportsble events or other events requiring notice to the Pansion Benofit Cuaranty Corpore. tion cecer during this plan yer?

1 " Yes" complete (o) through (h) below.

(e) Notifiertion by the Internal Revenue Sorvice thet the plan has ceased to be alan as described in Section $4021(a)(2)$ of ERISA or a determination by the Secratary of Labor of noncomplience with Title I of ERISA.

(b) A decreses in active particieants to the ertent specified in the instructions .

(s) A determination by the Internal Revenue Service thrt there has been a cermination or partial termination of the

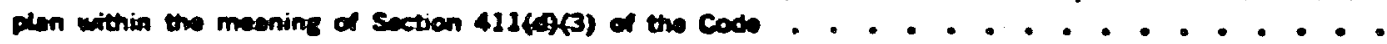

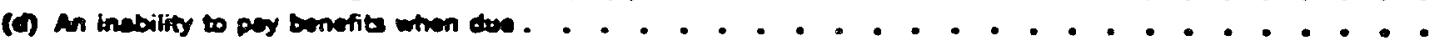

(o) A distribution to - Substantial awner to the extert specified in the insenctions . . . . . . . . . .

(1) An afternative mathod of complience has been prescribed for this plan by the Socretary of Labor under section 280 ef EArsa. . . . . . . . . . . . . . . . . . . . . . . . . . . . . . .

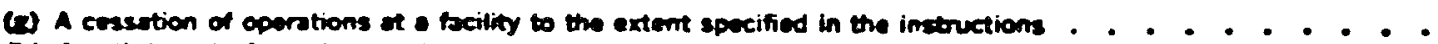
(i) A withdranal of a substantial employer.

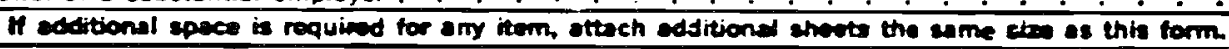

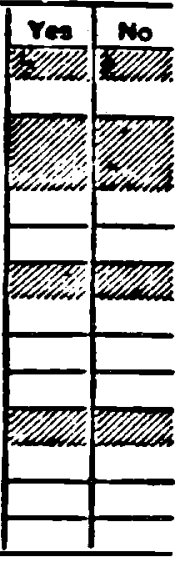




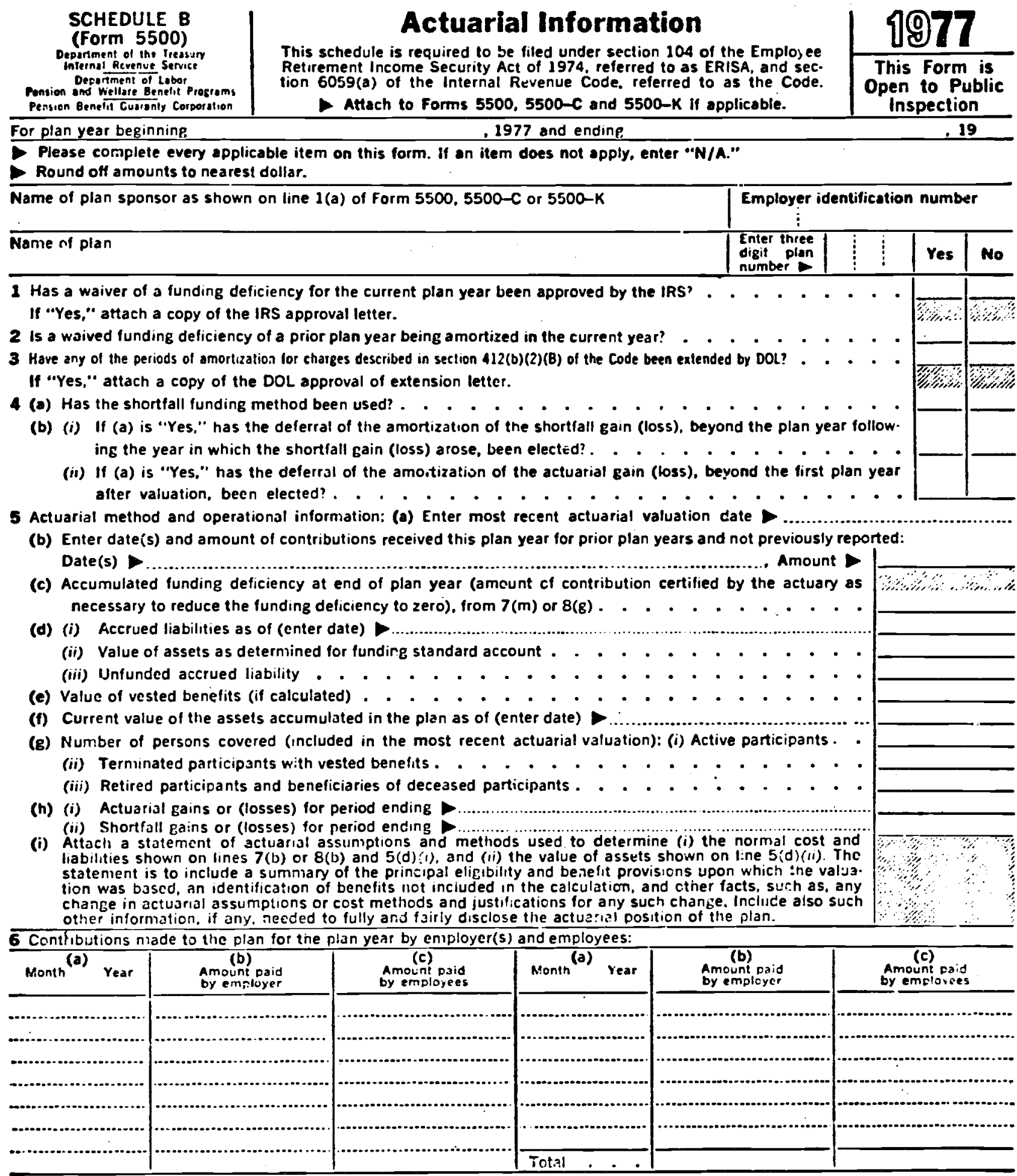

Statement by enrolled actuary (see in:structions before signing):

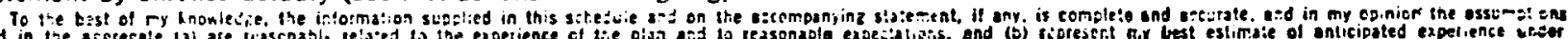
wast in 1 ine 


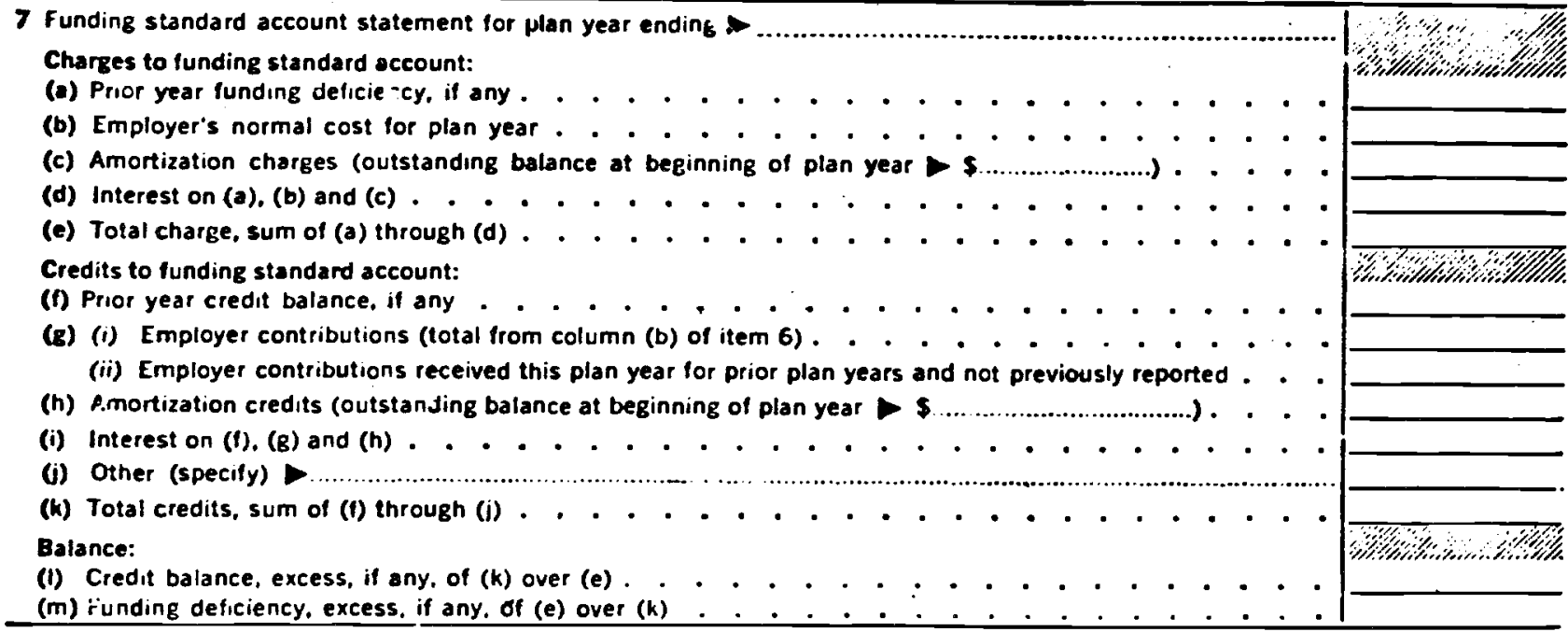

8 Alternative minimum funding standard account (omit if not used):

(a) Was the entry age normal cost method used to determine entries in item 7 above? . . . . . . . $\square$ Yes $\square$ No 11 "No." omit (b) through (B) below.

(b) Normal cost . . . . . . . . . . . . . . . . . . . . . . . . . . . . . . . .

(c) Excess, if any, of value of accrued be nefits over market value of assets . . . . . . . . . . . . . .

(d) Interest on (b) and (c) . . . . . . . . . . . . . . . . . . . . . . . . . .

(e) Employer contributions (total from column (b) of item 6) . . . . . . . . . . . . . . . . .

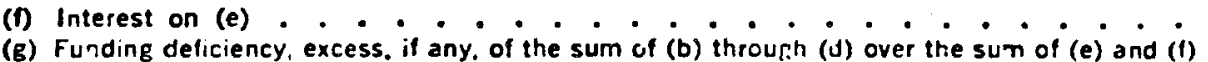

\section{Instructions}

Who Must Five. The employer or plain ad. ministratur of a defined bene?.t plan that is subject to the minimum funding standards (see section 412 of the Code and Par, 3 of Tille !
of ERISA) must tile this schedute as an allach. of $[R I S A)$ must tile this schedute as an altach.
ment to the annual return! report fited for plan ment 0 the annual return repart filed lor plan
years bezinning on or after January 1.1976. Years beginning on of after Januly 1.1976. Pans maintained on January 1.1974. pursuant to one or more collective bargarning a sreme nts
entered into before September 2 . 1974 . are not entered into be rore september 2. 1974. are not subject to the mirumum funding standarus for pian yea's beginning berore the earlier of the termination of the coliective
ment(s) or Jancary 1.1931 .

For splis.furided plans. the costs and contribu. pions reported on Sinedule $B$ should include those reia:t:ng to boin trust funos and insurance carriers.

\section{Specific Instructions}

(References are in line ilems on the form.)

4(a) A collectively tarpained plan only may elect tha shorlfall fund:ng method (see regula. tions under section 412 of the Codel. Adrance

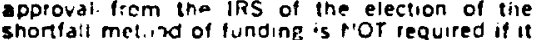
is tirs: a sopted on or before the later of (1) :he is firs: aucpled on or before the later of (1) :he hirst pian year to which section 412 of the Code opplies or (11) the last plan year commcncing appoval $1.0 m$ IRS is required, if adopted at a apporial rom IRS is required.

4(b) farance approval from IRS of the elec. tion to cetier the arrortization of the shotfall Eaiu (iss) ans or the amorization of the ac turial: ? $n$ (loss) is required for a plan year, sub. sea.. to the lirst plan ycar :o which ire shor. falf r.eliod applies. Aovance appioval trom IRS is required for discontinuance.

5(a) The valua:ion for a plan year may be as of ar.y da:e in the year. incluje:ree the first and

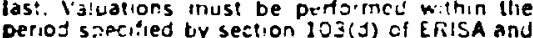
section $\mathrm{xi} 59$ (a) of the Cude.

5(b) inst arralisatip to the fiest fian year to whirh ene nunimum funoing standards apDiy. 5(c) Insert amount from item $7(\mathrm{~m})$. How ever. It the alternative method is elected. and item $B(\varepsilon)$ is smillict than item 7 (III) enter the amount rom item $8(r)$. File form 53 jo with the
Internal Revenue Serwice to pay the $5 \%$ excise Internal Revenue Serwice to pay
tax on the funding defisiency.

5(d) Amounts in 5(d) should all be as of the sanie date which should be the Jate it the end of the plan year or Oate as of which the most recent acluarial ialuation was made. if amounts are not as of the date of the most rezent actu. orial valuation. incicate in the s:atement of actuarial assumpt.ons and methods (as required by $5(t))$ now the amounts in $5(d)$ were deter. mined. Liabilities fully funded by annuity and insurance contracts other than any contract lunds not aliocated to individuals may be omitted from both items 5(d)(1) and 5(d)(ii).

$5(-1)(i)$ It the aggregate cost or frozen intial liability method is used, enter " $N$ /A."

5(d)(ii) Determine the value of asspts in ac. cordance nith section 412 (c)(2) of the cose or cordance hith section
$302(c)(2)$ of ERISA

$5(0)(: i i)$ If the assiegate cost or frozen intial liability metios is used. enter " $N / A$."

5 (1) This should be as of the same date as $5(d)$ or. "I not. the me:hod of adpustment be.
iwcen tie two dates should be indica:ted in 5 (1). $5(h)(i)$ if the agstegate cost or frozen intial liability method is uscd. enter " N/A

$5(h)($ ii) For the mothods to te used to de'er. mine ihe shorlfall gain (loss) see the recitiations uncer section 412 of the Code.

5(i) A summary of one pace or less of f:3n previsions witl oreinzelly be a.teauste. Fer ihe lirst year for which Sehedule B is rizulred to be thled. no charize in the actustial me!'od of asjumpions needs to the no:ed ar tustices. In subsequent years. a chiarse in artuanial meinod or o'en year requires ins aps:oral. Altuarral mathods should the cessrities in at

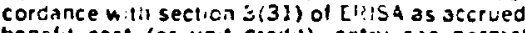
bencht cost (or unit credit), entry a:e normat cos: individual level prenium, are cizate cost. a!taned iae nornial cust or frosen initisl tia b.lity. whe'e those terms are applisidie. If the shorifall me:had of funding is usc J. all pertinent
facts relatin? to tundina peculiar to this meinod should be insiucco in t:: sia:enicni.
6 Show all employer and employee contribu. tions for the plan year. and employer contritutions made not later than $2 \%$ mioneths (or suen later date allowed under section $412(5)(10)$ of
the code and section $302(C)(10)$ of ERISA) atier the Code and section 30 ?

Statement by enrolied actuary.-In lieu of signing the staterrent. an enrollec actuary may allach signec statement containing the name. - odicss. entoliment number. telephone number and thi actuary's opinion that ine assumptions used in preparing Scheoule $B$ are in the aggre. gate ressonatly related to the expenience of the pian and to reasonabie expettations. and repre. sent his or her best es!niate of anticipated ex. perience under the pian ond to ine best of his or her knowledfe the report is comblete and ac. culate. In addition, the actuary may offer ary other comments related to the inforniation con. taince in Schedule $B$.

7 Under the shortall method of funding. the Nornial Cost in the funding standart account. is the chiarce per unit of production (or per unit of service) nuvitplied by the ac:ula number of units of proiucticn (or uitis "f service) which aicuried duing :ire plan year. Each aniontization insta!l. ment in the funding stansard account is similarly caiculated. For a pizn maintained by more than gain (loss) and tne actuasial gain (icss) may be delerred. See reğula:ions unúer section $\mathbf{4 1 2}$ of the code.

$7(b)$ II no viluation was made for the current yidr, en:er the recimal cost caiculaied in the most resell actuarial vaiuation. or the estimated cest fir tile current yeat based on slith valua. riast anouns are rot as of one suse ce the nist in ads (as requires ry s(j) how the a

$8(a)$ If the eniry ase normal cosi me:hed was not used to determine tne cntries in item 7 , the atternative ininimum funsing standaro account may not te used.

8(c) The value ol accrued bene?t:s should ex. cluse benefits aecrues lor ine surrent fidn year. The nisket value of aksass shouls te reduced rent fivil yedr. 
* This paper is a part of the National Bureau of Economic Research study of private pension funds. I am grateful to Arturo Estrella and Joyce Manchester for research assistance; to them, Jay Light, and the participants in the National Bureau pension project, including especially Fischer Black, for many helpful discussions and for comments on an earlier draft; and to the National Bureau and the Alfred P. Sloan Foundation for research support.

1. The 1977 "plan year" for purposes of Form 5500 is either the 1977 calendar year or the plan's fiscal year beginning in 1977. The plan sponsor has until seven months after the plan year ends to file the return.

2. A one-by-one inspection of the 384 plans reporting over $\$ 100 \mathrm{million}$ in assets suggested few obvious omissions among large corporate sponsors.

3. By contrast, the Federal Reserve System's flow-of-funds accounts reported total assets of private pension funds as $\$ 178$ billion at yearend 1977 and $\$ 198$ billion at yearend 1978. The Form 5500 data therefore confirm the widely acknowledged under-reporting in the flow-of-funds sample.

4. The largest single plan, sponsored by General Electric Co., reported assets of $\$ 3.8$ billion.

5. The great majority of companies sponsor five or fewer plans. The largest number of plans sponsored by any one company (excluding subsidiaries) was 63 . 
6. The computer program that searches for Compustat matches was developed by Clint Cumins; I am grateful to him for making the program available

7. The key to this part of the matching process was the Directory of Corporate Affiliations 1978 (Skokie: National Register Publishing Co., Inc., 1978). It would be difficult to overestimate the amount of painstaking effort devoted to this task by Arturo Estrella and Joyce Manchester.

8. Of the 1,836 consolidated plan sponsors, 1,571 sponsored defined benefit plans.

9. The pension sponsor with the largest amount of pension assets on a consolidated basis was American Telephone and Telegraph Co., with $\$ 18.4$ billion in assets held in 3 plans sponsored by the parent company and 26 plans sponsored by subsidiaries.

10. See, for example, the work of Black (1980), Feldstein and Seligman (1981), Oldfield (1977), Scholes (1981), Sharpe (1976) and Tepper (1981).

11. In many situations, a corporation's principal means of flexibility in this regard is its ability to choose what assumptions (interest rate, inflation rate, etc.) to use in calculating the actuarial value of the liabilities to be funded. See, for example, Tepper and Affleck (1974). A careful empirical study of corporations' behavior in this regard represents a potentially fruitful line of research, but one that lies beyond the scope of this paper; see section VI below.

12. U.S. corporations must report, as a footnote to the balance sheet, the difference between vested pension liabilities and the level of pension funding. Neither total need be stated individually, nor need the corporation report its non-vested liabilities at all (except on 
Form 5500 Schedule B).

13. Watever off-balance-sheet assets and liabilities the firm has, apart from $P A$ and $P L$, are included in $B A$ and $B L$ for purposes of this paper. See also footnote 34 below on the definition of PL.

14. The sample for this regression, and those reported in the following discussion, omits 13 firms for which net worth is sufficiently small that either $\frac{P L}{N W}$ or $\frac{F L}{N W}$ exceeds 3.0 . The result of a significant positive relationship also appears (although with smaller $\gamma$ values) when VL, the firm's vested pension liabilities only, is used in place of total pension liabilities PL. (The simple correlation between VI and PI within the total sample is .89.) It is interesting to note that regressions of the form (4) and also (5) below, estimated with $\mathrm{BA}$ instead of $\mathrm{NW}$ as the scale variable, typically show a small negative value of $\gamma$ which is marginally significant at the .05 level. By contrast, most of the results reported in this paper are essentially invariant to the choice of $\mathrm{NW}$ or $\mathrm{BA}$ as the scale variable; see footnote 16 below for the one other case in which this choice makes a substantive difference.

15. See also the paper by Harrison and Sharpe in this volume.

16. Defined benefit plans report total assets explicitly on Form 5500 and implicitly (as the difference between liabilities and unfunded liabilities) on Schedule B. The two asset measures need not coincide. For the 1977 sample, the simple correlation between the two is .92 in the disaggregated sample, and .95 in the aggregated sample. The results reported here and below rely on the asset measure implicit in Schedule B because it is more likely to be consistent with the 
liability measure. Here, as in (4), using vested liabilities vL in place of PL also consistently results in a significant positive relationship, but with smaller $\gamma$ values. In the regressions of the form (7) as well as (8) below, replacing NW by BA as the scale variable typically leads to small (in absolute value) values of $\gamma$, of either sign, that are not statistically significant; see again footnote 14.

17. The t-statistic associated with the explicit test of the null hypothesis $\delta=1$ is 28.2 , easily warranting rejection at any plausible confidence level. For the two subsample regressions described immediately below, the analogous $t$-statistics are 19.2 and 11.9 , respectively.

18. See especially Oldfield (1977) and Feldstein and Seligman (1981), as well as the paper by Feldstein and Morck in this volume. It is always possible, of course, that managements make decisions on the basis of believing that they can affect the share price in this way even if that belief is false.

19. These aggregate data are from the Federal Reserve System's flow-offunds accounts for yearend 1980. Although the proportions vary over time, primarily as a result of fluctuations in equity prices, the 1980 values are not atypical.

20. See Pesando (1981) for evidence on beneficiaries' implicit sharing in these returns, however.

21. See Black (1980) and Tepper (1981).

22. This statement abstracts from such factors as risk and maturity differences between the debt issued and the debt held.

23. For the subsample of firms with $P A / B A \geq .03$, the $\beta$ value for $\sigma$ (EBIT) 
in the equity equation is -.37 , with $t$-statistic -2.5 ; for the subsample with $\mathrm{PA} / \mathrm{BA} \geq .10$, it is -.75 , with t-statistic -2.2 .

24. Again this result carried over to all measures of earnings.

25. The corresponding $\beta$ values in the $P A D$ and $P A O$ equations were both negative, though not statistically significant.

26. This distinction between equity investment in the accumulation and the annuity phases of defined contribution pension plans corresponds to what many participants in TIAA-CREF voluntarily elect when they switch their pension reserves from CREF to TIAA at or near the time of retirement.

27. If the observations in the sample corresponded to different dates for the same firm, then a positive relationship between balance sheet leverage and pension asset allocations to debt securities would be evidence that firms behaved over time as Black (1980) and Tepper (1981) have suggested that they should for tax reasons. In a cross-section sample, however, no such inference would be warranted. At most, a positive cross-section relationship would indicate differences among firms in their extent of implementation of Black and Tepper's advice.

28. This positive relationship is opposite to what I found in earlier work based on a limited sample of Form 5500 and related data for plan year 1976 .

29. Using vested liabilities VL in place of PL in (15) does not substantially affect the estimated $\gamma$ values, but does reduce the associated t-statistics; for the two samples reported above the results based on VL are, respectively, $\gamma=.31$, with t-statistic $6.4\left(\bar{R}^{2}=.03\right)$, 
and $\gamma=.26$, with t-statistic $5.0\left(\bar{R}^{2}=.07\right)$.

30. The variability of the rate of return on equity affects other liabilities negatively in both the full sample and the PL/TA $\geq .10$ subsample.

31. Using vested liabilities VI in place of PI in (17) also consistently results in a significant positive relationship, but with smaller $\gamma$ values.

32. These results apply to the Schedule B value of assets. For the Form 5500 asset totals, which need not have the same date as the liabilities reported in Schedule $B$, corresponding results are $\gamma=.46$ and $\delta=-.32$, with respective t-statistics 8.9 and $-4.9\left(\bar{R}^{2}=.06\right)$ for the full sample, and $\gamma=.58$ and $\delta=-.40$, with respective t-statistics 8.7 and $-4.7\left(\bar{R}^{2}=.23\right)$ for the subsample.

33. The results for estimating (6) are comparable.

34. As Jay light points out in his discussion in this volume, there is also a problem if managements use differing actuarial concepts in defining pension "liabilities" - or, even if a single concept is used, if that concept differs importantly from that assumed here. The concept of pension "liabilities" used here (as in all of the previous literature cited above) is the actuarial present discounted value of accrued obligations for future benefit payments. This concept is identical to the notion of "actuarial present value of accumulated plan benefits" as defined by the Financial Accounting Standards Board (FASB) in its Statement No. 35, adopted March, 1980 (see especially pp. 6-9). What matters here, however, is what concepts managements used at the time when they submitted their 
companies' reports for the 1977 plan year. On the basis of a close reading of the pension handbooks and texts available at that time, as well as the few available surveys of pension actuarial practice, it is not possible to determine whether - or to what extent managements relied on the concept used here, which was later formalized by FASB-35, or the different net concept suggested by Light, or yet some other interpretation. The question does bear importantly on the empirical work in this paper, as well as in all other empirical studies involving pension liability data before FASB- 35 . 


\section{References}

Black, Fischer. 1980. "The tax consequences of long-run pension policy." Financial Analysts Journal 36: 25-31.

Feldstein, Martin and Seligman, Stephanie. 1981. "Pension funding, share prices, and national savings." Journal of Finance 36: 801-824. Oldfield, George S. 1977. "Financial aspects of the private pension system." Journal of Money Credit and Banking 9: 48-54.

Pesando, James. 1981. "Employee valuation of pension claims and the impact of indexing initiatives." Mimeo, National Bureau of Economic Research.

Scholes, Myron. 1981. "Investigation of the Tepper/Black funding and allocation theory." Mimeo, National Bureau of Economic Research. Sharpe, William F. 1976. "Corporate pension funding policy." Journal of Financial Economics 3: 183-193.

Tepper, Irwin. 1981. "Taxation and corporate pension policy." Journal of Finance $36:$ 1-14.

Tepper, Irwin, and Affleck, A.R.P. 1974. "Pension plan liabilities and corporate financial strategies." Journal of Finance 29: 1549-1564. 